\title{
Paleoecological and paleoenvironmental changes during the continental Middle-Late Permian transition at the SE Iberian Ranges, Spain
}

\author{
R. De la Horra a,*, A.B. Galán-Abellán a , J. López-Gómez a, N.D. Sheldon ${ }^{\text {b }}$, J.F. Barrenechea ${ }^{\text {c }}$, \\ F.J. Luque ${ }^{c}$, A. Arche ${ }^{a}$, M.I. Benito ${ }^{a}$

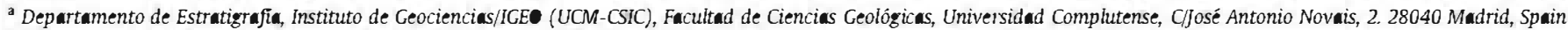 \\ b Department of Earth and Environmental Sciences, University of Michigan, 1100 N. University Avenue, Ann Arbor, MI 48103, United States \\ ' Departamento de Cristalografia y Mineralogía, Instituto de Geociencias/IGE (UCM-CSIC), Facuitad de Ciencias Geológicas, Universidad Complutense, C/José Antonio Novais, \\ 2. 28040 Madrid, Spain
}

\section{Keywords:}

Middle-Late Permian

Mid-Capitanian

Extinction

Paleoenvironmental changes

Iberian Ranges

\begin{abstract}
A B S T R A C T
The Middle and Late Permian are characterized by a pair of mass-extinction events that are recorded in both marine and continental environments. Here, we present the first continental western peri-Tethyan record of an extinction event located in the Middle-Late interval. In the SE Iberian Ranges, Central Spain, the transition between the Lower and Middle subunits of the Middle Permian Alcotas Formation indicates a significant paleoclimatic change from arid and semiarid conditions towards more humid conditions. Coincident with the onset of humid conditions there were changes in the sedimentology, mineralogy, and geochemistry that indicate significant environmental changes including a shift in weathering intensity and a change of fluvial style from braided to meandering systems. Near the top of the Middle Subunit, a local biotic crisis is recorded by palynomorph assemblages. Following this crisis, there is a total absence of coal beds, plant remains, and microflora that defines a barren zone in the uppermost part of the Alcotas Formation which is recorded throughout the basin. The barren zone is accompanied by a shift back to braided stream systems, but not by a return to carbonate-bearing paleosols indicative of arid or semi-arid conditions. This combination of features is consistent with other Middle-late continental basins related with mass extinctions, so the barren zone is interpreted as the extinction interval. The regional character of the extinction interval and its proximity with the Middle-Iate Permian transition could be related with the global mid-Capitanian biotic turnover described in this period of time in other marine basins. However, the common difficulties of dating with precision non-marine rocks make this relationship difficult to probe in the Iberian Basin and in other Middlelate Permian basins. Further work, including high resolution carbon-isotope analyses and complete studies of the magnetostratigraphy, should be desirable in order to obtain a better age constraint and to produce reliable comparisons with marine sections.
\end{abstract}

\section{Introduction}

The Middle-Iate Permian transition was marked by one of the major biotic crises of the Phanerozoic, comparable in magnitude with the so-called "Big Five" mass extinctions (Wang and Sugiyama, 2000; Yang et al., 2004), and considered as the first step of the taxonomic transition from the Paleozoic to the modern fauna of the Mesozoic (Knoll et al., 1996; Clapham and Bottjer, 2006). In the oceans, $58 \%$ of invertebrate genera disappeared (Knoll et al., 1996) and numerous groups of corals, bryozoans, brachiopods, bivalves, and ammonoids were affected (Clapham et al., 2009; Isozaki, 2009), with extreme extinction losses in the fusulinaceans (Jin et al., 1994; Leven 2003; Iai et al., 2008). On land, the floral communities of South and North China (Wang, 2009; Stevens et al., 2011), Antarctica, and Karoo Basin (Retallack et al., 2006, 2011) suffered notable changes, which were also observed in the record of terrestrial vertebrates, although it is not clear that the continental and marine extinctions were synchronous (Lucas, 2009). This biotic event is known as the end-Guadalupian extinction (Jin et al., 1994; Stanley and Yang, 1994).

Clapham et al. (2009) recently suggested that the end-Guadalupian extinction was not an abrupt loss of taxonomic diversity but a gradual decrease in biodiversity from the Wordian to the end of the Permian. However, most other Permian researchers infer instead a rapid extinction event (Jin et al., 1994; Retallack et al., 2006; Bond and Wignall, 2009; Wignall et al., 2009), though there is no consensus on the precise timing of the onset of the event or of its duration. For example, the main extinction level has been identified in the last part of the Guadalupian (Yang et al., 2004; Dongying and Wenchen, 2006; Retallack et al., 2006; Isozaki, 2009), earlier in the Woardian-Capitanian transition (Gand and Durand, 2006; Lucas, 2009) and in the middle of the 
Capitanian Stage (Bond et al., 2010a, b), or even later in the early Lopingian (Nielsen and Shen, 2004; Kaiho et al., 2005). Iack of precise geochronological control of stratigraphic sections could be, in part, responsible for this disparity of opinions, although the most recent and detailed studies in the marine realm, which are dated with conodonts and foraminifers, locate the extinction level in the mid-Capitanian (Middle Permian) (Bond et al., 2010a; Wignall et al., 2012). Moreover, Wignall et al. (2012) find no evidence for an extinction event at the end of the Guadalupian, and suggest that previous claims for an end-Guadalupian mass extinction are based on poorly dated records of a mid-Capitanian event. According to the most recent references (Bond et al., 2010a,b; Wignall et al., 2012), the Middle Permian biotic crisis will be referred to as "mid-Capitanian" for the rest of this paper, even if other authors referred to it as "end-Guadalupian".

Similarly, the cause or causes of the extinction are also debated, although the eruption of the Emeishan Large Igneous Province has been implicated as the main cause by many authors (Wignall, 2001,2005; Ali et al., 2002; Zhou et al., 2002; He et al., 2007; Wignall et al., 2009; Bond et al., 2010a; Sobolev et al., 2011). Other extinction mechanisms have been also considered, such as the Kamura event, an episode of high productivity on the ocean followed by global cooling (Ponomarenko, 2006; Isozaki et al, 2007; Clapham et al., 2009), oceanic anoxia (Wignall and Twitchett, 1996; Nielsen and Shen, 2004; Isozali et al., 2007) or sea-level changes (Hallam and Wignall, 1999; Shen and Shu, 2005). In the recent literature, there are many papers indicating that most of these perturbations approximately coincided with the main extinction event, making it difficult to unravel the relative significance of each one individually (Lai et al., 2008), but recent works found no evidence of anoxia (Wignall et al., 2010) and essentially leave volcanism as the prime culprit (Bond et al., 2010b).

However, there are some consistent signals among the better studied marine and continental sections, where Middle-Late extinctions were marked by a large extinction event, followed by a relatively sharp, large magnitude ( $>3 \%$ ) negative carbon isotopic excursion (Wang et al., 2004; Kaiho et al., 2005; Retallack et al., 2006; Isozaki, 2009; Bond et al., 2010a), and a rapid change of the paleoclimatic conditions. Recent works focused on Middle-Late Permian rocks point to paleo-environmental changes related to sea-level change, global cooling after a high productive episode, transition from highto low-sinuosity fluvial systems, and shifts toward warm-wet climatic conditions in most continental records (Hallam and Wignall, 1999; Ward et al., 2000; Retallack et al., 2006; Isozaki et al., 2007; Lai et al., 2008; Retallack et al., 2011).

In this paper, we present a multidisciplinary study that includes stratigraphical, biotic and geochemical data in order to describe the temporal evolution of the continental environments of the Alcotas Formation, located in the Iberian Ranges, eastern Iberia. The results represent the first set of data from the continental Middle-Late transition in the western peri-Tethyan region.

\section{Geological setting}

During the Middle Permian-Early Triassic, the Iberian Plate was near the margin of the western part of the Tethys Sea, close to the intertropical convergence zone (Stampfli and Borel 2002; Dinarés-Turell et al., 2005). Due to the extensional collapse of the Variscan Belt and the westward propagation of the Neotethys, a complex system of rift basins developed in Central and Western Europe (Ziegler and Stampfli, 2001; Vargas et al., 2009). On the Iberian Plate, three main rift systems accommodated a complicated Permian to Cenozoic record that, after tectonic inversion, formed the Pyrenean-Cantabrian mountain belt, the Catalan Coastal Ranges and the Iberian Ranges (De Vicente et al., 2009) (Fig. 1). In the former Iberian Basin, a long sedimentary succession was deposited during the Early Permian time (Salas and Casas, 1993; Arche and López-Gómez, 1996; van Wees et al., 1998) in localized zones with intense subsidence, probably related to strike-slip tectonics (De Vicente et al., 2009). These Early Permian basins developed on a deformed Variscan basement composed of Ordovician-Silurian slates and quartzites that had been subjected to low-grade metamorphism (López-Gómez et al., 2002).

As in the rest of the Iberian Peninsula, the Permian rocks in the Iberian Basin are mainly represented by alluvial fan and fluvial deposits, although some volcaniclastic units are also intercalated within early Permian sediments (Hernando et al., 1980; lago et al., 2005). Continental sedimentary depositional settings lasted until Anisian (Middle Triassic) time, when the Tethys Sea reached the eastern Iberian Plate margin and carbonate ramps in Muschelkalk facies onlapped the continental red beds of Buntsandstein facies (Arche and López-Gómez, 1999) (Fig. 2).

The Permian rocks in the SE Iberian Ranges, represented by the Tabarreña, Boniches and Alcotas formations (Fig. 2) are well-exposed and preserve significant lateral extents (Fig. 1). These units have been studied from a variety of different approaches including paleogeography, paleotectonics, paleontology, and sedimentology (López-Gómez and Arche, 1992, 1993a, 1994, 1997; Benito et al., 2005; López-Gómez et al., 2005a, b; De la Horra et al, 2008).

The Alcotas Formation is unconformably overlain by Triassic rocks (Fig. 2), so the Permian-Triassic boundary is not preserved in the study area. As in all of the western and central basins of Europe, this unconformity is represented by a hiatus that corresponds to the upper Lopingian, but which probably lasted until Olenekian time (López-Gómez et al., 2005b; Bourquin et al., 2011). The first Mesozoic sedimentary record in the SE Iberian Ranges is represented by the Valdemeca Unit (De la Horra et al., 2005), which consists of sandy and gravelly, channelized stream deposits with a radial pattern of paleocurrents, and unconfined sheet flood deposits. These characteristics are interpreted as the result of deposition of a stream-channel alluvial-fan system. The presence of windblown desert sands and wind abraded clasts or ventifacts, together with the general absence of a vegetated cover, is suggestive of arid to very arid climatic conditions during this period of time (Bourquin et al., 2011).

The Cañizar Formation (López-Gómez and Arche, 1993b) is the most representative continental unit of the Early-Middle Triassic in the Iberian Ranges. It is composed of red sandstones, which represent channel-fill deposits by means of migrating bedforms, mainly linguoid and transverse bars. Overbank fines and floodplain sediments are practically absent, and this unit is interpreted as sandy braided fluvial systems flowing to the SE.

\section{Methodology}

Seven lithos atigraphic sections of the Alcotas Formation were measured in detail, described in terms of sedimentology, and sampled for laboratory analysis (Figs. 1 and 3). Where applicable, paleosols were identified using a combination of horizonation, color, root races, and race fossils, and classified into the USDA soil taxonomic scheme (Soil Survey Staff, 1999). Our sampling includes both fossil specimens and fresh rock samples of representative profiles of paleosols, and samples of pedogenically unaltered sandstone. Some of our paleontological results, based on fragments of fossil plants and positive palynological data, have already been published (Diéguez and Barrón. 2005; Diéguez and I.ópez-Gómez, 2005; Diéguez et al., 2007). Collected rock samples were prepared for standard transmitted light microscopy, electron microprobe analyses (EMPA), identification of clay mineralogy by X-ray diffraction (XRD), whole rock geochemisy (ICP-OES/MS), and stable carbon isotope measurement (EA-IRMS).

Polished and uncovered $30-\mu \mathrm{m}$ thin sections were prepared for transmitted light microscopy and analyses in a JEOL JXA-8900M WD/ED electron microprobe with an accelerating voltage of $15 \mathrm{kV}$ and a spot size of $5 \mu \mathrm{m}$. Detection limits were $100 \mathrm{ppm}$ for $\mathrm{Mg}$, $250 \mathrm{ppm}$ for Sr, $200 \mathrm{ppm}$ for Mn, $250 \mathrm{ppm}$ for Fe, and $140 \mathrm{ppm}$ for $\mathrm{Na}$. 


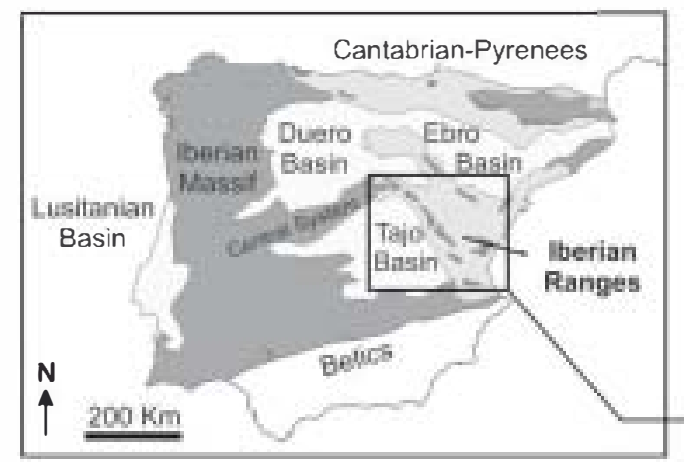

Neogene and Quaternary

Cenozoic

Cretaceous-Jurassic

Permian-Triassic

Undifferentiated basement

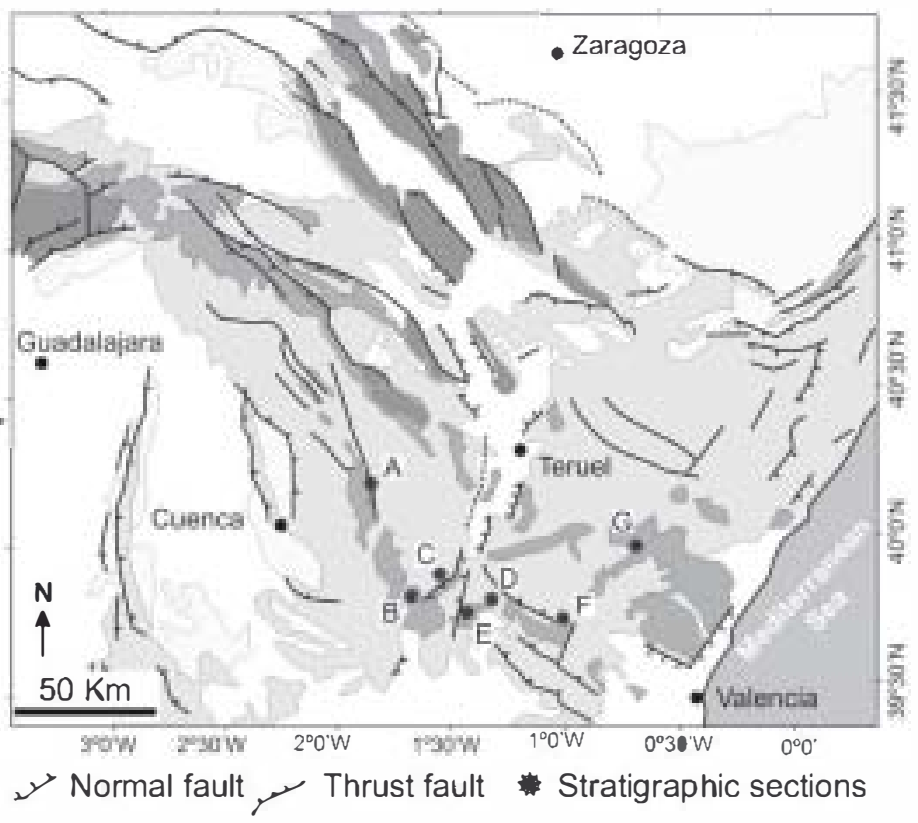

$\checkmark$ Normal fault Thrust fault Stratigraphic sections

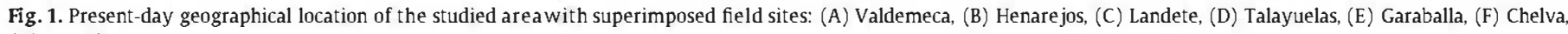
(G) Montán.

Bulk mineralogy was determined by X-ray diffraction (XRD) after grinding and homogenization of samples to $<53 \mu \mathrm{m}$. Random-oriented powders were examined on a Siemens Kristalloflex 810 diffractometer, using Cu-K $\alpha$ at $30 \mathrm{kV}$ and $40 \mathrm{~mA}$, a step size of $0.03\left({ }^{\circ} 2 \theta\right)$, and time per step of $1 \mathrm{~s}$ ( $\mathrm{scan}$ rate of $1.8^{\circ} 2 \theta \mathrm{min}^{-1}$ ). The clay mineral composition was determined on oriented aggregates of the $<2 \mu \mathrm{m}$ fraction obtained by sedimentation from an aqueous suspension onto glass slides. In some cases, the samples were subjected to thermal treatment at $550{ }^{\circ} \mathrm{C}$ for $2 \mathrm{~h}$ and to dissolution with ethylene glycol (EG). A slower scan rate $\left(1.2^{\circ} 2 \theta \mathrm{min}^{-1}\right)$ was used between $2^{\circ}$ and $13^{\circ} 2 \theta$ in order to obtain better defined peaks.

The intensity of the post-sedimentary processes was determined with the full-width-half-maximum (FWHM) of the illite $10 \mathrm{~A}^{\circ}$ peak (the so-called Kübler index, KI), that was measured on the XRD patterns of the air-dried oriented aggregates using the Diffrac Plus EVA 10.0 software. Our raw data were recalculated after calibration using reference polished slate slabs according to the procedure suggested by Kisch et al. (2004). The raw data can be transformed by the formula: $y=1.0059 \times-0.0493$. Therefore, the lower and upper limits of the anchizone are $0.38^{\circ}$ and $0.21^{\circ} \Delta 2 \theta$, respectively.

Geochemistry of major, minor, and race elements of 44 paleosol samples were analyzed with a Perkin Elmer Optima 3300RL Inductively Coupled Plasma-Atomic Emission Spectrometer (ICP-AES) located at the Royal Holloway University of London (RHUL). Analytical uncertainty was typically less than 0.1 wt.\% for major elements, and $0.1-2$ ppm for most trace elements. Stable isotope analyses followed standard procedures where samples were rinsed, crushed, and decarbonated using weak $(7 \%) \mathrm{HCl}$. The resulting residues were ground using a mortar and pestle and placed in tightly crimped tin capsules for analysis of the carbon isotopic composition of the samples at RHUL using an optima isotope ratio mass-spectrometer (IRMS) coupled to a Fisons NCS1500 elemental analyzer (EA). Results are reported in delta notation (e.g., $\delta^{13} \mathrm{C}$ ) relative to the VPDB scale and were calibrated using a combination of internal and intemational standards. Analytical uncertainty was less than $0.1 \%$. All of the geochemical data are archived in the Data Repository.

\section{Permian strata and age control}

All of the Permian rocks of the SE Iberian Ranges are of continental origin. Although there are important hiatuses in the sedimentary record, the general stratigraphic nomenclature is well-defined (López-Gómez and Arche, 1992, 1993a; Arche and López-Gómez, 1996; López-Gómez et al., 2002; Benito et al., 2005; De la Horra et al., 2008). From base to top, three formations have been differentiated: Tabarreña, Boniches and Alcotas Formations (Fig. 2).

The Tabarreña Formation crops out in a series of isolated and small basins separated by local highs of Variscan rocks. It is composed of clay matrix-supported red breccias with angular fragments of quartzite and slate (Fig. 2A) related to rockslide and debris flow processes, although fluvial strata have been recognized at the top of the unit (López-Gómez and Arche, 1994). The Tabarreña Formation has been included in the first major sedimentary cycle of the Iberian Basin and based on comparisons with other equivalent sediments in the NW Iberian Ranges, interpreted as of Lower Permian age (Arche et al., 2004). An angular unconformity separates these rocks from the overlying Boniches Formation.

The Boniches Formation is composed of clast-supported conglomerates of well-rounded quartzite clasts with a reduced proportion of slates $(<1 \%)$ only present in the beds close to the basement. The matrix is medium-grained and arkosic, with minor components of illite, pyrophyllite and kaolinite in the clay-size fraction. These components occur in variable proportions in the lower and middle parts of the Boniches Formation, but in the upper part, the kaolinite and pyrophyllite show a clear and progressive decrease, disappearing at the top of this formation (Alonso-Azcárate et al., 1997; López-Gómez and Arche, 1997). This formation represents the beginning of the second sedimentary cycle in the evolution of the Iberian Basin (Arche and López-Gómez, 1996) and lies unconformably on the Variscan basement of quartzites and slates or, locally, on the Tabarreña Formation (Fig. 2B). The age of the Boniches Formation has been established by pollen and spore associations as Thüringian (Doubinger et al., 1990). "Thüringian" is a well-known western European term defined for Upper Permian pollen assemblages, but it is not a formally accepted time unit (Diez et al., 2005; Lucas et al., 2006). It is, however, commonly accepted that the Thüringian correlates well with the Tatarian Stage of the Russian Platform, which in turn, has been broadly correlated to the Capitanian and the Wuchiapingian (Menning et al., 2006; Ogg et al., 2008). The Boniches Formation contains characteristic Thüringian species, such as Luekisporites virkkiae, but Vittatina and Potonieisporites of Autunian (Lower Permian) affinity are still present 

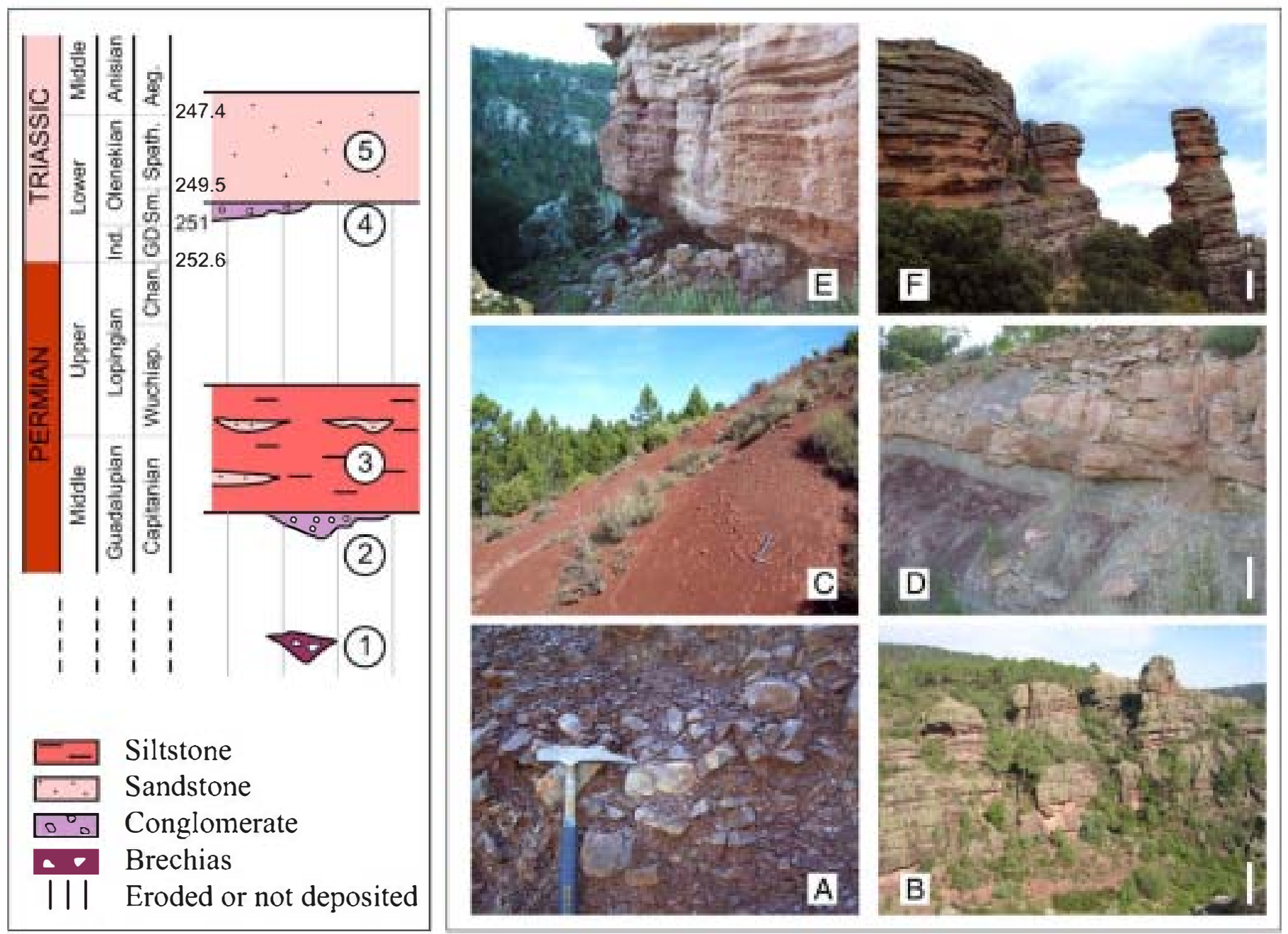

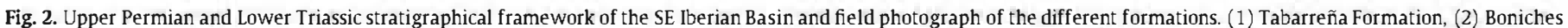

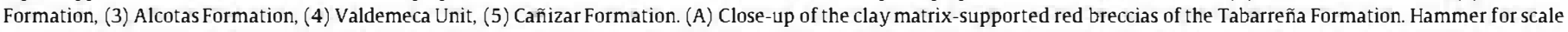

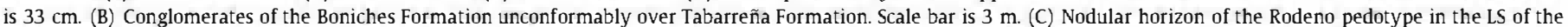

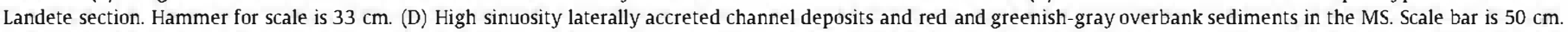

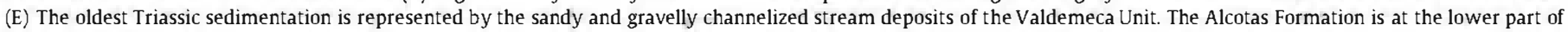

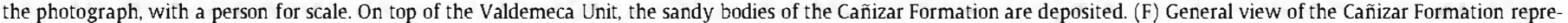
sented by sandy braided fluvial systems. Scale bar is $3 \mathrm{~m}$.

(Doubinger et al., 1990), hence this formation is clearly older than the overlying Alcotas Formation (see below).

The Alcotas Formation, with a thickness up to $170 \mathrm{~m}$, consists of red mudstones and siltstones, intercalated red to pink sandstone levels with some conglomerate lenses located at the base of the western sections, and paleosols (Fig. 2). Locally, the Alcotas Formation lies conformably on the Boniches Formation or unconformably on the Variscan basement. In the study area, an unconformity separates the Alcotas Formation from the overlying Valdemeca and Cañizar formations, which represent the stratigraphically lowest Triassic rocks. The age of the Alcotas Formation was estimated by means of different pollen and spore assemblages, which were identified as Thüringian (Doubinger et al., 1990; Diéguez and Barrón, 2005), implying a Capitanian-Wuchiapingian age $(\approx$ Thüringian $)$.Although the application of standard palynologic techniques in continental settings has a limited chronostratigraphic precision (Lucas et al., 2006), recent studies (Arche and López-Gómez, 2005) suggested an early Lopingian (Wuchiapingian) age based on comparison with the Russian platform assemblages studied by Gorsky et al. (2003). In detail, Nuskoisporites dulhuntyi, which occurs up to the Middle Subunit of the Alcotas Formation, is restricted to the Middle-Late Permian of western, central and southern Europe, with first-occurrences not earlier than Wordian times (Poort et al., 1997), and Potonieisporites, which is present in the Boniches Formations and absent in the palinological data of the Alcotas Formation and lateral equivalents, does not occur in the Zechstein (Doubinger et al., 1990). Best estimations (Slowakiewicz et al., 2009) locate the base of the Zechstein at the GuadalupianLopingian Boundary, and thus, based on microflora, the Boniches Formation is interpreted to be older than $260.4 \mathrm{Ma}$. On the other hand, a preliminary paleomagnetic study of the Alcotas Formation (De la Horra, 2008) confirmed that the deposition of this unit was characterized by normal and reverse intervals of polarity. Frequent polarity changes were previously described by Turner et al. (1989) in the lateral equivalent of the Alcotas Formation in northwestern sections. This fact implies that the Alcotas Formation is younger than the Illawarra Reversal that has been lately located very close to the Woardian-Capitanian boundary (ca 265.8 $\pm 0.7 \mathrm{Ma}$; Isozaki, 2009). As the contact between the Boniches and the Alcotas formations is transitional, and the Boniches Formation is not younger than $260.4 \mathrm{Ma}$, based on the combination of palinological and paleomagnetic data this study locates the lower part of the Alcotas Formation in the period of time between 265.8 and 260.4, close to the Middle-Late Permian transition. 


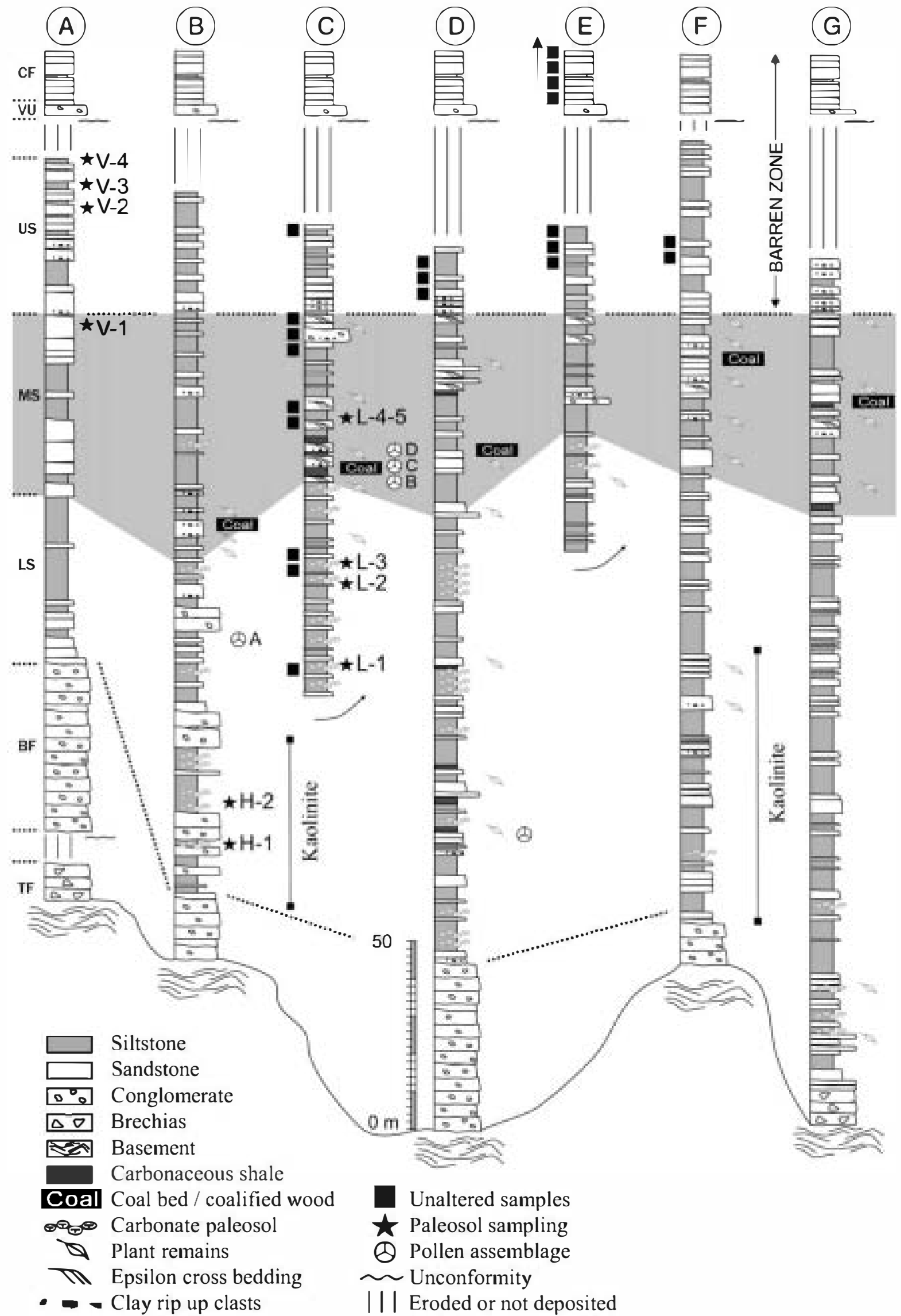




\section{Results and interpretation of the Alcotas Formation}

The Alcotas Formation has been divided into three subunits: Lower (LS), Middle (MS), and Upper (US) (Arche and Iópez-Gómez, 2005; De la Horra et al., 2008). These subunits can be differentiated and laterally traced in most of the studied sections along the SE Iberian Basin (Fig. 3). In the next sections we will describe the Alcotas Formation in detail.

\subsection{Fluvial style}

The sedimentology of the Alcotas Fomiation and its northwestem equivalents has been reviewed by Ramos (1979), Pérez-Arlucea and Sopeña (1985), López-Gómez and Arche (1986), Sopeña et al. (1988), and Arche and López-Gómez (1999, 2005). In the SE Iberian Ranges, the three subunits of the Alcotas Formation show distinctive sedimentological features and fluvial styles.

The oldest subunit (LS) consists of red siltstones with intercalated lens-shaped sandstone bodies 95-120 $\mathrm{m}$ wide and 4-6 $\mathrm{m}$ thick, with erosional bases and flat tops. Towards the bases of some stratigraphic sections, these bodies can be composed of conglomerates. In general, the rocks are composed of incomplete fining-upward sequences with trough and planar cross-stratification at the base and current ripples and siltstones at the top, which is generally bioturbated. These sequences are separated by meter-scale bodies of red massive siltstones with development of carbonate-bearing paleosols (De la Horra et al., 2008). This part of the Alcotas Fomıation is interpreted as the result of permanent to semi-permanent sandy or gravely braided river systems crossing wide floodplain areas towards the SE, with instability of the active channels and a high avulsion rate (Archea nd López-Gómez, 2005).

A significant change in depositional style marks the transition between the IS and MS. The frequency of sandstone bodies in MS increases and overall, there are fewer fine-grained sedimentary units. Dispersed quartz clasts are abundant at the base of the sandstone bodies, which show trough and planar cross-stratification, channelized geometries that may be single- or multi-storey, and white to greenish colors. In the MS, the fining-upward sequences are characterized by epsilon cross-stratification (lateral accretion) structures, with abundant plant remains, bioturbated tops, and large (up to $6 \mathrm{~m}$ long) fragments of silicified trunks (Diéguez and López-Gómez, 2005). The type of paleosols preserved also differs from the $L S$ because they are poorly developed, with sandy textures, and lack carbonate horizons. The color of the siltstones also changes appreciably, because while the red color is still predominant, gray, black and green are very frequent. Finally, a wider range of paleocurrent directions is observed, varying from $N 60^{\circ}$ to $265^{\circ}$. This subunit is interpreted as permanent sandy fluvial systems of medium-high sinuosity, running through vegetated floodplains with isolated ponds.

The return to semi-permanent braided systems, with paleocurrents pointing to the SE. characterizes the youngest subunit of the Alcotas Formation. Channelized sandstones are normally single-storey although multi-storey sandstones are locally observed. In general, they consist of decimeter-scale fining-upward sequences with rough and planar cross-stratification and clay rip-up clasts at their erosive bases. Sporadically, there are current ripples at the top, although these sequences are normally incomplete (Arche and López-Gómez, 2005). Gray, black, and green colors are absent, and the rocks are generally dark red or purple in color. Bioturbation is almost absent; there is no coal, plant, or tree trunk that remains in this unit, and only scarce, isolated, and weakly developed non-carbonate paleosols are observed locally at the uppermost part of the nothwestern sections (De la Horra et al., 2008; Figs. 1 and 3).

\subsection{Paleobotany}

The macro and microflora of the Alcotas Formation have been described in several previous publications (Doubinger et al., 1990; Diéguez and Barrón, 2005; López-Gómez et al., 2005a; Bourquin et al., 2007: Diéguez et al., 2007; Diez et al., 2007). Most of these descriptions emphasize the important sudden decline in the paleoflora content recorded at the MS-US transition.

\subsubsection{Microflora}

To date, only LS and MS have produced positive palynomorph assemblages (Fig. 3). Moreover, in all the Iberian Peninsula, there are no younger palynological data recorded until the first Anisian (Middle Triassic) palynoflora (Doubinger et al., 1990; Diez et al., 2005, 2010; Grauvogel-Stamm and Ash, 2005: López-Gómez et al., 2005b).

The assemblages of the Alcotas Formation are quantitatively rich in Klausipollenites schaubergeri and Lueckisporites virkkiae, defining typical Thüringian palynofloras. Diéguez and Barrón (2005) differentiated four associations that, from oldest to youngest, are ordered as follows: A-Klausipollenites-Lueckisporites, B-AlisporitesLueckisporites, C-Klausipollenites-falcisporites and again D-KlausipollenitesLueckisporites (Fig. 3). These palynomorph assemblages, mostly are dominated by non-striate bisaccate pollen and verrucate spores, comprising allochtonous elements derived from upland levees, distal and drier parts of floodplains and extrabasinal areas that were inhabited by conifers, pteridosperms and other xerophyllous-mesophyllous plants (gnetopsids). Para-autochtonous assemblages, including lycopsids and some ferns typical of lowland environments, such as floodplains, are also represented.

In a broad sense, the pollen record indicates the presence of dense gymnosperm woodlands, which correlates well with the fact that conifer forests of Majonicaceae, Utrechtiaeae and Ullmanniaceae were dominant in Europe during the Middle-Late Permian (looy et al., 1999). In detail, the quantitative evaluation of Diéguez and Barrón (2005) makes it possible to establish different stages in the vegetation dynamics of the Alcotas Formation. The A association, found in LS, corresponds with a low density forest, with scattered trees and very poor shrubland vegetation. The B association, obtained in the lower part of the MS, shows an increase in diversity and population density, as well as an increase of lycopsids, interpreted as a clear expansion of humid environments. A decrease of the herbaceous vegetation (lycopsids and ferns) is recorded by the $C$ association, although a dense conifer forest, mainly composed of Pinopsida, is still present. The younger $\mathrm{D}$ association records the lowest diversity of taxa and a dramatically reduced population density. Lycopsids, ferns, gymnospeıms and pteridosperms diminished considerably in population, as well as all the groups of Pinopsida. Of these, only Majonicaceae, the producers of Lueckisporites virkkiae, remained with a similar number of taxa, because of its high ecological plasticity and high adaptation to all kinds of environmental conditions.

Qualitative and quantitative analyses carried out by Diéguez and Barrón (2005) indicate the absence of transitional floras between the $\mathrm{C}$ and $\mathrm{D}$ assemblages, and a profound dieback of taxa that ranges from $35 \%$ to $67 \%$ depending on the group, along with lower overall diversity within meters of the MS-US transition (Fig. 3). As a result, Diéguez and Barrón (2005) identified that stratigraphic interval has at least a local biotic crisis.

\subsubsection{Macroflora}

The pattern of change in both macrofloral remains and palynological assemblages is similar. In spite of the low number of specimens and the poor state of preservation, the macroflora of the Alcotas 
Formation also shows important upsection changes in diversity and population density. Diéguez et al. (2007) observed four different zones in the Alcotas Formation, the oldest (A) is located in LS, and the other three (B to D) in MS. No macroflora remains have been identified from the US to date. Zone A comprises leafy shoots and caules of gymnosperms, impressions of cordaitalean and utrechtiacean axes, sometimes highly carbonized, and well-preserved vegetative shoots. A significant increase in diversity and population density is observed in the next zone (B), which it is located in MS and shows reproductive structures, remains of leaves, trunks and indeterminate caules of sphenopsids, cordaitales and conifers. Zone $\mathrm{C}$ records a significant decrease in macrofloral remains, and the scarce specimens collected mainly correspond to silicified conifer trunk fragments, some of which are also carbon-rich. In the youngest zone (D), the low number of macrofloral remains basically corresponds to silicified trunks and vegetative shoots of Majonicaceae. Near the top of the MS a $6.2 \mathrm{~m}$ Dadoxylon sp. trunk shows the presence of lignin decay in the tracheids of the secondary xylem that have been interpreted by Diéguez and López-Gómez (2005) as the result of activity of saprophytic fungi, probably related to a generalized dieback of arboreal vegetation.

\subsection{Mineralogy and petrography}

The main mineralogical and petrographic characteristics of LS, MS, and US subunits are summarized in Fig. 4, which is based on field observations, QFR sandstone classification of 183 thin sections, and clay mineral identification by XRD.

The mineralogy of fine-grained sediments is basically constituted by detrital illite $(38-84 \%)$, quartz $(8-43 \%)$, albite (around $4 \%$ ), hematite $(0-5 \%)$, and kaolinite $(0-15 \%)$, with minor components of illmenite, dolomite and lepidocrocite. Hematite is found in lowest in MS, and kaolinite is only found in the basal part of LS, in Henarejos and Chelva sections (Figs. 3, and 4A). Similar results were obtained by Alonso-Azcárate et al. (1997), who related the presence of kaolinite to the development of kaolinitic saprolites on the Variscan basement of the source area formed under humid climatic conditions.

The higher content of carbonate in LS is obvious in the field (Fig. 2C) due to the presence of several nodular and petrocalcic pedogenic levels found in Inceptisols and Aridisols (De la Horra et al., 2008). The original mineralogy and texture of the carbonate have been altered by diagenesis, and now we observe coarse crystals of dolomite and/or magnesite. The carbonate precursor of some paleosols is preserved only in the Talayuelas section, where it is composed of non-ferroan and dark red luminescent dolomicrite. In addition, the uppermost paleosols of LS at the Iandete section have lenticular pseudomorphs of siderite, which are now composed of goethite, calcite, and ankerite (Benito et al., 2005). Pseudomorphs of siderite are also frequently observed at MS in some stratigraphic sections, but not in the US. The presence of siderite in this subunit could indicate formation in a reducing environment, circum-neutral $\mathrm{pH}$ and high concentration of $\mathrm{CO}_{2}$ in the soil (Sheldon and Tabor, 2009). Although the content of carbonate decreases significantly in the MS, with only scarce nodules and weakly developed paleosols, it is in the US where carbonates are completely absent in the study area (Fig. 4A).

The presence of coal layers and pseudomorphs of pyrite is limited to the MS. Coal is generally preserved as dispersed filaments and lenses up to $2 \mathrm{~cm}$ thick, although in the Chelva section it can reach thicknesses of up to $40 \mathrm{~cm}$. Pseudomorphs of pyrite, now altered to iron oxi-hydroxides, occur with metallic luster and dark red or black
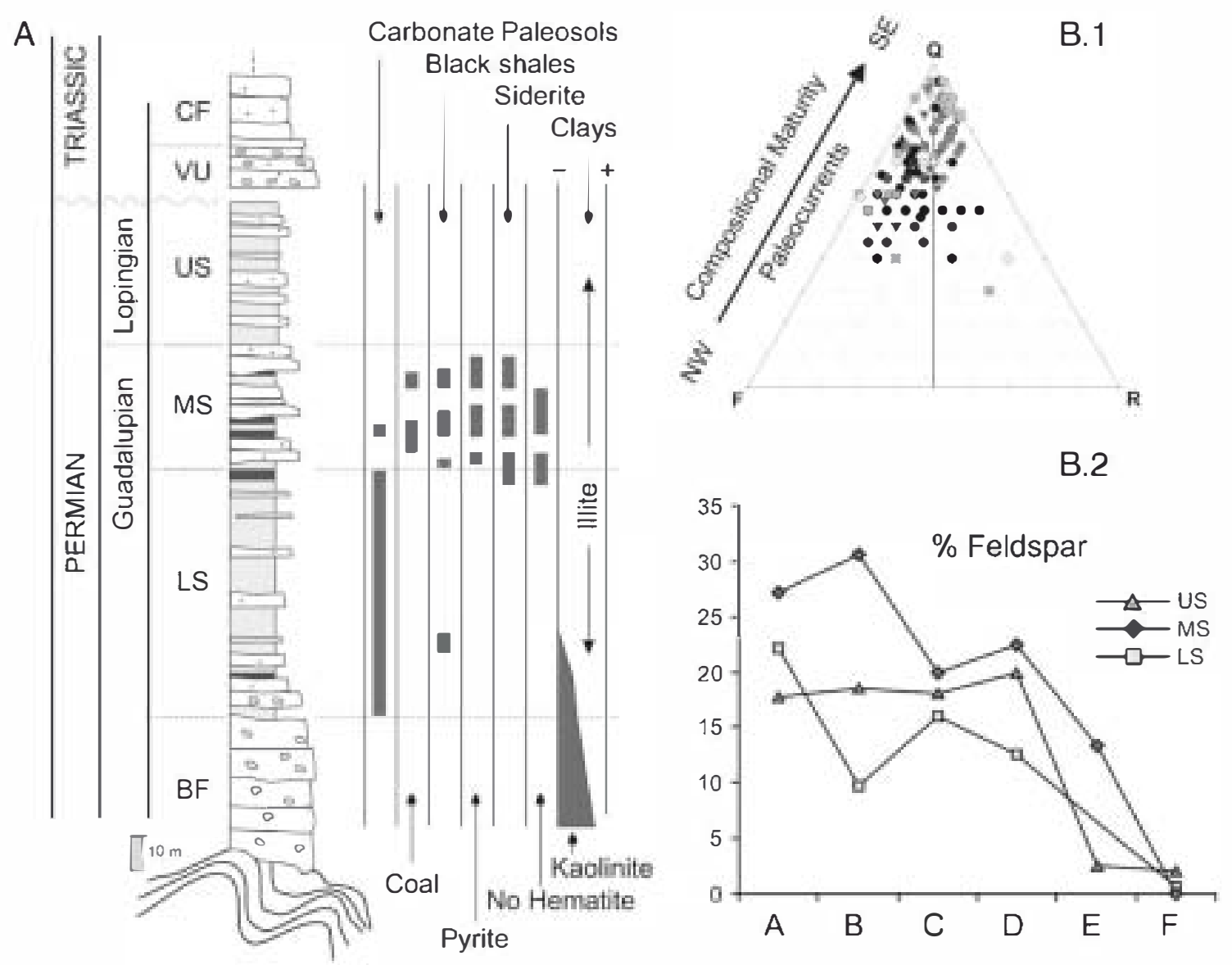

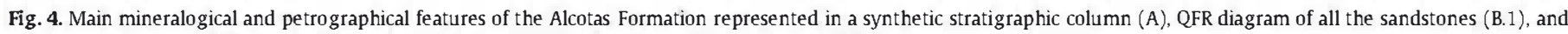
relative abundance of feldspars in thin section (B.2). See Fig. 1 for locations of the field sites. Lithologic symbols as in Fig. 3. 
colors as euhedral crystals, with cubic habits, and size between 1 and $2 \mathrm{~mm}$, although larger crystals (up to $1 \mathrm{~cm}$ ) are also observed. Aggregates of small pyrite crystals $(0.3-1 \mathrm{~mm})$ are also observed in thin sections. Apart from one thin level in the Talayuelas section, there are not gray/black and green siltstones in the LS, which is generally red instead (Fig. 2C; Fig. 4A). In contrast, dark gray/green colors are common in the MS (Fig. 2D), usually in association with fossil plant accumulations, coal levels, pseudomorphs after pyrite, and iron-oxide mottled sandstones. All of these characteristics are essentially restricted to the MS, and are characteristic of locally reducing or mixed redox conditions (Kraus and Aslan, 1993; Sheldon, 2005).

Sandstones of the Alcotas Formation mostly range in composition from subarkose to arkose, although quartz arenites and sublithic arenites are also present. A clear trend from arkoses to sublithic arenites is related to the paleocurrent direction towards the southeast (Fig. 4B.1), which indicates that the sediments deposited further from the source area are increasingly compositionally mature. However, a higher proportion of feldspar is recorded in the MS with respect to the other subunits (Fig. 4B.2). The increase of feldspar content is coincident with the change in fluvial style described by Arche and López-Gómez (2005) in the MS, and is probably related to the reactivation of the fluvial activity observed by Pérez-Arlucea and Sopeña (1985) in sections of the Albarracin area. In the northwestern sections of the studied area, the return to semi-permanent braided systems described in the US is coincident with a change in the mineralogy of the sediments from the arkoses and subarkoses of the MS to a substantial proportion of greywackes in the US.

\subsection{Paleopedology}

Benito et al. (2005) and De la Horra et al. (2008) reported the first description and classification of the paleosol profiles in the Alcotas Formation. From the base to the top of the formation, these authors recognized a change in the type of paleosols, and related the change to variations in fluvial styles, vegetation dynamics, or mineralogical characteristics.

The IS is characterized by well-developed Aridisols with calcareous nodules (Rodeno pedotype) or petrocalcic horizons (Pedrizas pedotype) (Fig. 5). Although both intrabasinal and extrabasinal processes can influence depositional and erosion patterns and, thus, control the type of soil formed, in the Alcotas Formation a significant regional climatic imprint is observed. In the LS, the Rodeno pedotype is dominant. It contains abundant carbonate nodules at a shallow level $(<1 \mathrm{~m})$ in the profile, and was classified by De la Horra et al. (2008) into the soil order Aridisol as a Typic Haplocalcid in the USDA Soil Taxonomy System (Soil Survey Staff, 1999). Although the recognition of the original mineralogy of the carbonate in the Bk horizons is difficult due to diagenetic alteration after burial (Benito et al., 2011), the presence of pedogenic carbonate is an important feature that indicates relatively dry paleoclimatic conditions (Royer, 1999; Retallack, 2005). Precipitation of carbonate in soils is mainly related to evapotranspiration, acidity of soil solutions, temperature, and availability of metal cations, all factors linked in some way to climatic conditions (Retallack, 2001; Alonso-Zarza, 2003; Sheldon and Tabor, 2009). Observed field features and preservation of dolomicrite in some thin sections suggest that these paleosols originally were well-drained dolocretes, developed under an arid to semiarid climate, with seasonal precipitation and high evapotranspiration conditions (Benito et al., 2005).

A change in the type of paleosols occurs in the MS. In this subunit there is a predominance of weakly developed sandy paleosols that were poorly drained, lack calcareous horizons, and which formed under more humid conditions (Arenal pedotype). In contrast, paleosols are very scarce in the US. Only a few poor-developed soils, without calcareous horizons (Corralizas and Asadores pedotypes), are observed in the last meters of this subunit, but only in the northwestern sections (De la Horra et al., 2008; Figs. 3 and 5).

In modern soils, the presence of carbonate is generally an indicator of some seasonal degree of aridity, because under constant wet conditions carbonate is not stable (Goudie, 1973; Mack and James, 1994; Retallack, 2001, 2005; Alonso-Zarza, 2003). On the basis of this, many authors have developed different methods to estimate the Mean Annual Precipitation (MAP) from carbonate paleosols of different ages. The measurement of the depth from the surface to the carbonate precipitation level has been widely applied (Retallack, 2001, 2005; Alonso-Zarza, 2003) because the depth of this horizon below the surface reflects the depth of wetting of the soil by available water, and therefore under dry climates, the calcic horizon is closer to the surface than in wetter paleoclimatic conditions (Retallack, 2001). Although this method has inherent limitations (e.g., incomplete profile preservation; Royer, 1999; Retallack, 2001) in general terms soils receiving less than $760 \mathrm{~mm} \mathrm{yr}^{-1}$ would have discrete carbonate horizons (Mack and James, 1994; Royer, 1999; Alonso-Zarza, 2003). Dispersed nodular carbonate will only form under wetter conditions if the climate was strongly monsoonal (e.g., Driese et al., 2005; Retallack, 2005) or if the paleosol represented an aggradational surface, therefore the upper boundary mean-annual-precipitation value for calcrete formation is estimated to be around $1000-1200 \mathrm{~mm} \mathrm{yr}^{-1}$ (Royer, 1999; Retallack, 2001; Alonso-Zarza, 2003).

In order to calculate the MAP, we have measured the depth to the carbonate horizon from the surface of the paleosol and applied the transfer function of Retallack (2005), which is considered a reasonably accurate proxy $\left(R^{2}=0.52\right)$. The mean annual range of precipitation or seasonality is inferred from the thickness of soil with nodules (Retallack, 2005). We have corrected the effect of burial compaction in each profile using the method of Sheldon and Retallack (2001). Because there are no carbonate-bearing paleosols in the US, only the results obtained from the LS and the lower part of the MS are plotted in Fig. 6. Calculated MAP values range from 237 to $499 \pm 147 \mathrm{~mm} \mathrm{yr}^{-1}$, indicating arid to semiarid conditions. The highest MAP and seasonality values were found in the basal part of the Alcotas Formation, which also preserves kaolinite, a mineral typically indicative of soils under MAP regimens over $500 \mathrm{~mm} \mathrm{yr}-{ }^{1}$ (Retallack, 2001). The lack of paleosols in the US in every section makes it difficult to interpret the paleoclimatic conditions, however, in the northwestern sections, the studied paleosols have drab-haloed root traces, greenish mottling and desiccation cracks, suggesting moderate to good drainage conditions and seasonal waterlogging, consistent with pale precipitation estimates from paleosol chemistry (see Section 5.5).

\subsection{Bulk-rock geochemistry of paleosols}

A number of different proxies based on bulk-rock geochemistry of paleosols have been derived for reconstructing paleoenvironmental and paleoclimatic conditions (reviewed in Sheldon and Tabor, 2009), and have been applied previously to Permian-Triassic continental rocks (Retallack et al., 2003; Sheldon, 2005, 2006; Coney et al., 2007). However, in order to exclude sedimentary inheritance or a provenance change as the primary cause of geochemical variability, a number of other factors must be carefully considered, including sample grain size, diagenesis, and the presence of pedogenic carbonate.

The addition of clastic sediments to paleosols from source areas of different composition could produce geochemical variations in their profiles that would otherwise be interpreted in terms of paleoenvironmental change. One way to investigate this issue is through the use of major and trace element ratios. For example, the molar ratio of $\mathrm{Ti}$ to $\mathrm{Al}$, where both elements are typically immobile during chemical weathering, should be constant in samples with the same parent material (Tabor et al., 2004; Sheldon, 2006). Other proxies based on ratios between trace elements of similar 

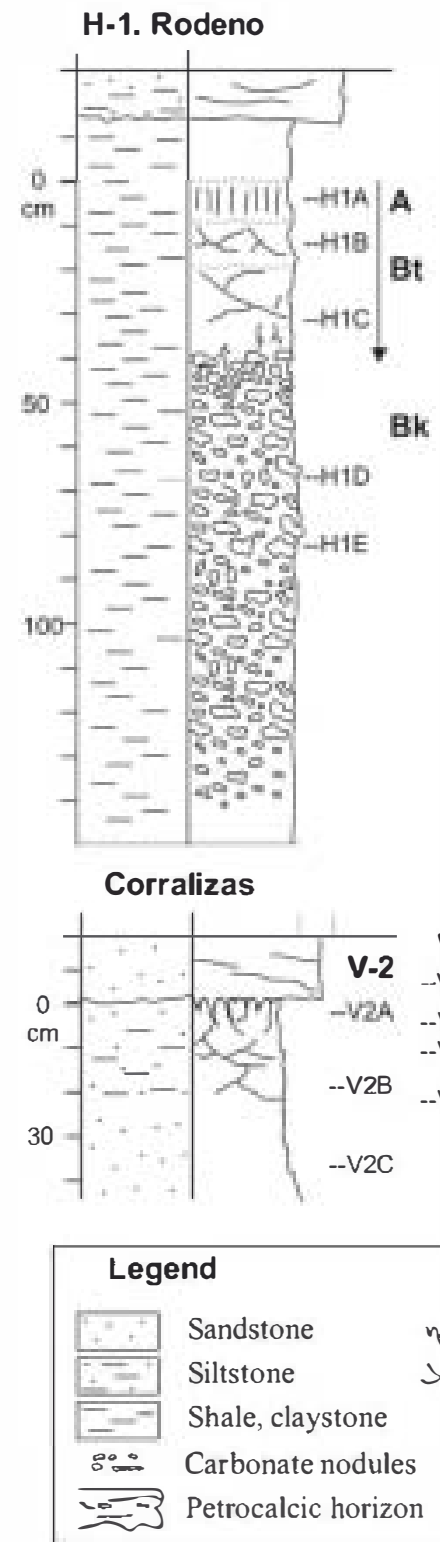
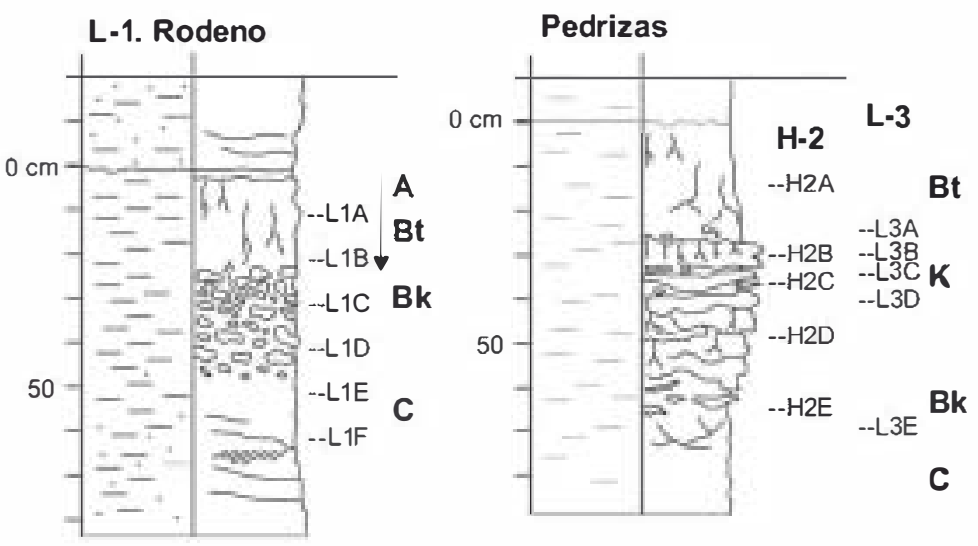
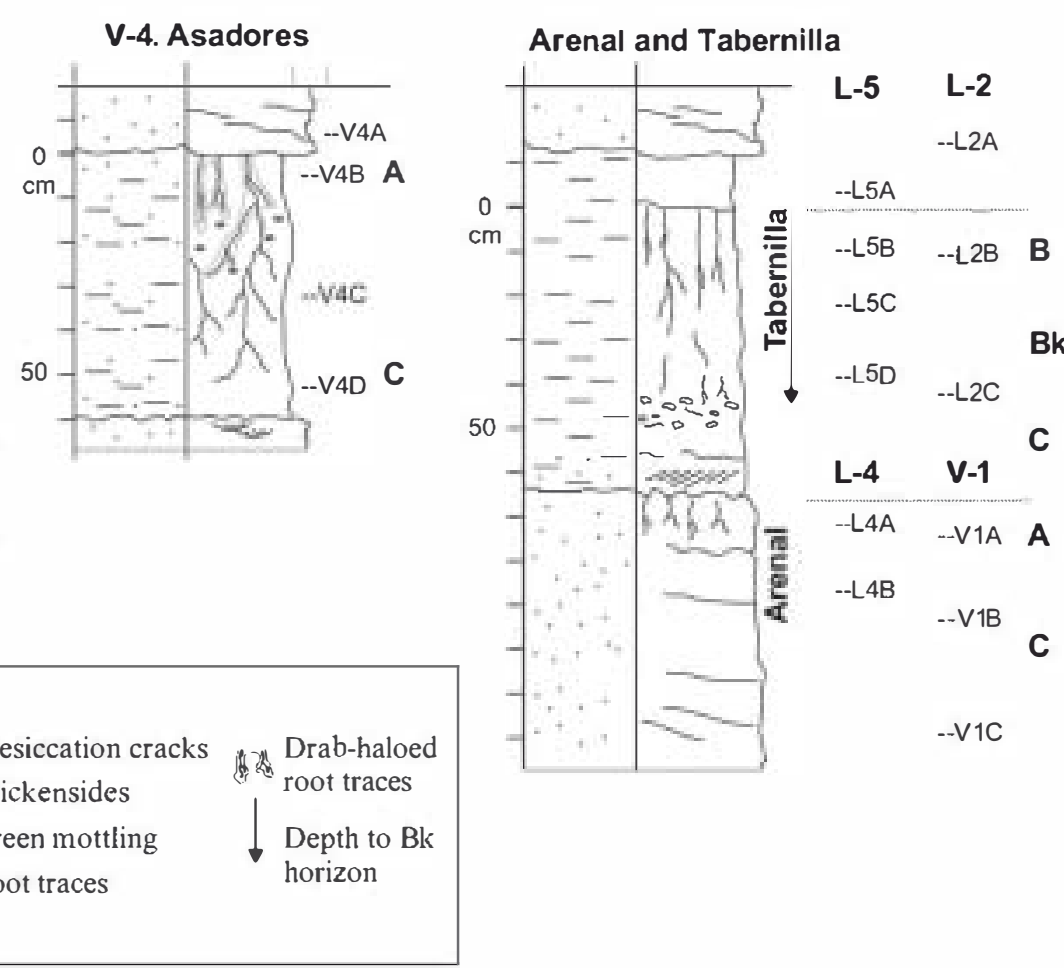

Fig. 5. Sampled paleosol profiles with main pedogenic features. Lithologic symbols as in Fig. 3.

solubility include $\mathrm{La} / \mathrm{Ce}, \mathrm{Yb} / \mathrm{Lu}$, and $\mathrm{Sm} / \mathrm{Nd}$. None of these ratios vary significantly either stratigraphically or laterally (Supplemental Table 2), which suggests a common provenance for all of the paleosols.

Although the geochemical results indicate a similar composition in source area for all of the paleosols, there are geochemical variations between different types of paleosols (e.g., as a function of maturity) and as a function of profile depth through different horizons. Previous sedimentologic work suggests that the variations between pedotypes are mainly due to differences in texture and the presence of carbonate horizons (De la Horra et al., 2008). These features could be related, in turn, to environmental conditions, formation time, and paleogeographic position in the landscape. With respect to grain size, the Arenal pedotype (Figs. 3 and 5: V-1, L-5) has a sandy texture, whereas the Corralizas and Asadores pedotypes (Figs. 3 and 5: V-2, V-3, V-4) are clayey to silty paleosols with a minor content of small-mediumsize grains, and the Tabernilla, Rodeno, and Pedrizas (Figs. 3 and 5: H-1, H-2, L-1, L-2, L-3, L-4) are mainly clayey paleosols. Therefore, the variation of the weathering index $\mathrm{Si} /(\mathrm{Al}+\mathrm{Fe})$, which is commonly high in sandy soils and low in clayey ferruginous soils (Retallack,
2001), is mainly due to the variations of grain size (Supplemental Table 2).

The intra-profile variations are instead interpreted as evidence of pedogenesis: accumulation of secondary carbonate in Bk and $\mathbf{K}$ horizons, clay illuviation into B horizons, or subsurface leaching. Paleosols of the LS have thick $\mathrm{Bk}$ and $\mathbf{K}$ horizons and therefore, higher molar $(\mathrm{Ca}+\mathrm{Mg}) / \mathrm{Al}$ values than those of the MS and US. The accumulation of $\mathrm{Ca}$ and $\mathrm{Mg}$ results in sharp decreases in $\mathrm{Si}, \mathrm{Al}, \mathrm{Na}, \mathrm{K}$, and $\mathrm{Ti}$ in the $\mathrm{Bk}$ and $\mathbf{K}$ horizons (Supplemental Table 1). Similarly, evidence of clay illuviation can be resolved using the molecular ratio of alumina to bases $(\mathrm{Al} /(\mathrm{Ca}+\mathbf{M g}+\mathbf{K}+\mathrm{Na}))$ in paleosol $\mathbf{B}$ horizons. A molar ratio of alumina/bases of $>2$ is found in mature and deeply weathered soils like Ultisols and Oxisols, but in fertile soils of moderate development, it is less than 2 (Sheldon et al., 2002). Evidence of illuviation is most pronounced in profile $\mathrm{H} 1$ (Fig. 5), which is consistent with the presence of kaolinite in the lower part of the IS (Figs. 3 and 4 ). The other paleosols instead have alumina/bases ratios of $<2$, with the L1, L2, L3, L4 and H2 profiles preserving low aluminum/ base ratios consistent with having been alkaline soils under arid and semiarid paleoclimatic conditions (e.g., Retallack, 2001). 

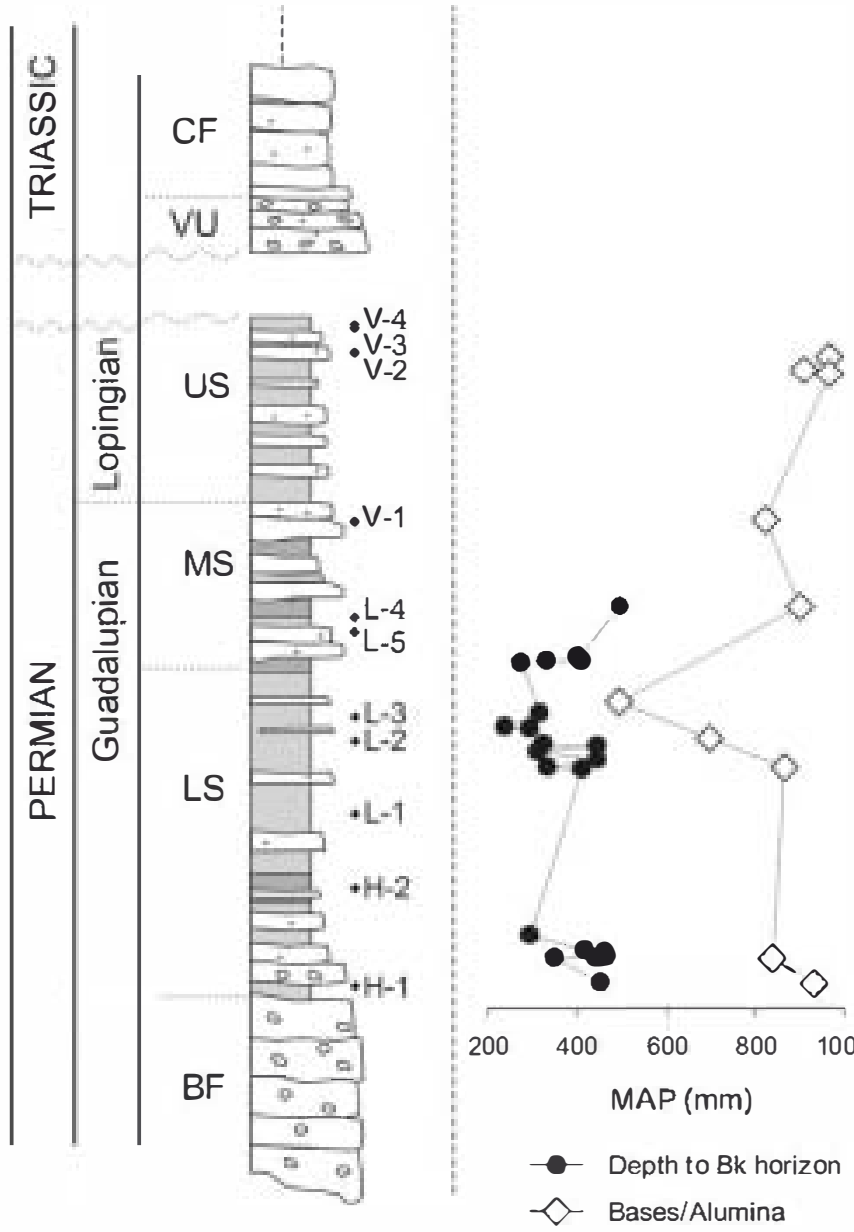

Fig. 6. Synthetic stratigraphic log of the Alcotas Formation with location of paleosols and estimations of the paleoprecipitation.

Based on empirical relationships derived from modern soils, Sheldon et al. (2002) proposed a quantitative proxy that relates the leaching of base cations to MAP with reasonable accuracy $\left(\mathrm{R}^{2}=\right.$ 0.66). In modern soils, leaching of base cations is limited in arid settings (high $\sum$ Bases/Alumina) and enhanced in humid settings (low $\sum$ Bases/Alumina). In Fig. 6, we have compared the MAP obtained from the depth to the Bk horizons with the MAP estimation based on $\sum$ Bases/Alumina $=(\mathrm{Ca}+\mathbf{K}+\mathbf{M g}+\mathrm{Na}) /$ Al. Although the standard error of the climofunction is $\pm 235 \mathrm{~mm} \mathrm{yr}^{-1}$, the geochemical results still imply systematically higher MAP than the Bk depth results. This relationship between the two proxies has been noted before (e.g. Sheldon and Tabor, 2009). However, in the IS both methods show a progressive tendency towards more arid conditions from a humid climate with marked seasonal regimes interrupted by a humid episode in the MS that coincides in the field with the lack of carbonate paleosols and the presence of coal layers, so both proxy results are consistent with the sedimentological evidence. In general, though the geochemical results are nominally less precise, comparison with independent proxies (e.g., paleobotanical MAP estimates) suggests that the geochemical results are generally more accurate (Sheldon et al., 2002; Driese et al., 2005).

Another means of assessing weathering intensity (i.e., leaching) is with the $\mathrm{Ba} / \mathrm{Sr}$ ratio, because both elements have similar chemical and atomic properties, but $\mathrm{Sr}$ is significantly more soluble than $\mathrm{Ba}$ (Sheldon and Tabor, 2009). Thus, a leached horizon should have a high $\mathrm{Ba} / \mathrm{Sr}$ ratio when compared to the parent material or $\mathrm{C}$ horizon. Values of $\mathrm{Ba} / \mathrm{Sr}$ in excess of 2 are found in sandy texture soils and under acidic conditions (Retallack, 2001). Fig. 7A shows the $\mathrm{Ba} / \mathrm{Sr}$ ratio obtained from the subsurface $B$ horizons of the paleosol profiles. Well-developed paleosols, such as the Pedrizas pedotype (H2 and $\mathrm{L} 3$ ) and the Rodeno pedoype ( $\mathrm{H} 1$ ), show high values of $\mathrm{Ba} / \mathrm{Sr}$, indicative of strong leaching conditions in the LS. High values are also found in the MS ( 14 profile), but in general due to the sandy texture of its paleosols the $\mathrm{Ba} / \mathrm{Sr}$ ratio is around 2 . Anomalous values $<2$ are characteristic in the upper part of the US. It is important to point out that those very low $\mathrm{Ba} / \mathrm{Sr}$ values in the US cannot be interpreted as variations in chemical weathering intensity because they are related to the $\mathrm{Sr}$ enrichment observed in the paleosols of this subunit (Fig. 7B), which was essentially constant in the MS and the LS.

In the MS and the US strontium and phosphorus are strongly correlated. The $\mathrm{P}_{2} \mathrm{O}_{5} / \mathrm{Sr}$ correlation coefficients of the subunits are: $\mathrm{LS}=$ $0.30, \mathrm{MS}=0.79$, and US $=0.94$. In the Triassic Cañizar Formation, high contents of $\mathrm{Sr}$ and $\mathrm{P}_{2} \mathrm{O}_{5}$ have been recently related to the presence of aluminum-phosphate-sulfate minerals (APS) that are solid solutions among svanbergite, woodhouseite, goyazite and crandallite (Galán-Abellán et al., 2009). Those studies indicate that the formation of the APS minerals took place shortly after sedimentation, during a period of increased weathering (with low $\mathrm{pH}$ and oxidizing conditions), and that the APS precipitation is associated with increasing amounts of La and $\mathrm{Ce}$. To date, we have not found APS in the Alcotas Formation, and the Sr variations are not related to changes in the abundances of $\mathrm{Ia}$ and $\mathrm{Ce}$ (Fig, 7B). Although we have not observed any petrographical criteria, the variations of $\mathrm{P}_{2} \mathrm{O}_{5}$ and $\mathrm{Sr}$ in US are best explained by an external input. The increase of $\mathrm{P}_{2} \mathrm{O}_{5}$ could be related to changes in the concentration of detrital phosphate-rich accessory minerals like apatite, but the source of $\mathrm{Sr}$ is more difficult to explain. However, the increasing of these elements could be related to a volcanic event. Air-fall volcanic ash might be a likely source of strontium and probably a complementary source of phosphorous in our samples. Recently, in the eastern area of the Iberian Ranges, Lago et al. (2011) have described the presence of subvolcanic rocks intercalated with the upper part of the Alcotas Formation. Although the time of emplacement of the basaltic andesite sills is uncertain as radiometric ages are not still available, these authors suggest that the emplacement of the sills took place soon after sedimentation. Although further studies are required, the possibility of a link between volcanism and the observed perturbations in the US of the Alcotas Formation is very tempting.

\subsection{Carbon isotopes}

In the recent literature there are many examples of marked negative ${ }^{13} \mathrm{C}$ excursions of stable carbon isotopes linked to the biotic crisis level at the Permian Triassic Boundary (PTB) in marine environments (Baud et al., 1989; Erwin, 1993; Kaiho et al., 2005; Yin et al., 2007), and relatively few for the mid-Capitanian (Bond et al., 2010a; Wignall et al, 2012). Generally this intra-Capitanian event in marine rocks is related to a negative excursion that occurred in two or three steps following unusually high positive ${ }^{13} C_{\text {carb }}$ values (Bond et al., 2010a), interpreted as a high bio-productivity event known as the "Kamura event" (Isozaki et al., 2007, Isozaki, 2009). This Middle to Iate Guadalupian event suggests a burial of a huge amount of organic carbon, draw-down of atmospheric $\mathrm{CO}_{2}$ and a drastic global cooling that could be the cause of extinction of large-shelled Tethyan fusulines and bivalves adapted to warm climate. Negative carbon isotopic excursions of at least $-4 \%$ in $\delta^{13} \mathrm{C}_{\mathrm{org}}$ are best explained by a release to the atmosphere of large amounts of methane of very isotopically depleted composition $\left(\delta^{13} \mathrm{C} \sim-60 \%\right)$, that would reduce the average $\delta^{13} \mathrm{C}$ composition of the atmosphere (Retallack et al, 2006). However, the consistent gradual decline of values described by Bond et al. (2010a) in South China is best explained by a thermogenic source.

Considering a continuous carbon exchange between the atmosphere, the hydrosphere, and the biosphere, samples of different lithology and fossil contents were collected, with the expectation that an atmosphere with very isotopically depleted $\delta^{13} \mathrm{C}$ composition 

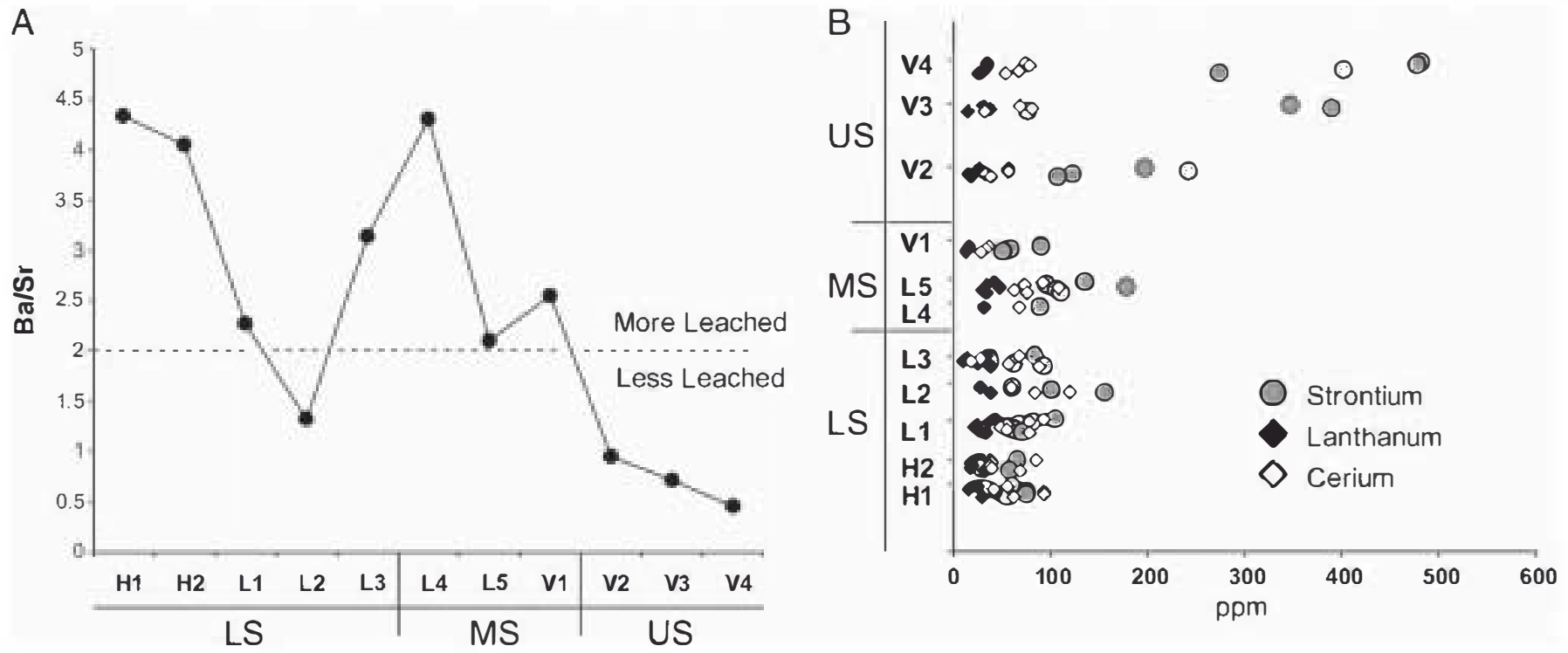

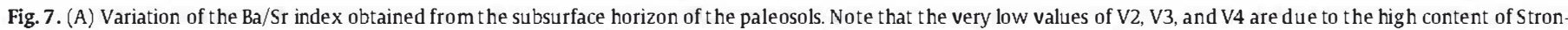
tium that characterizes the US (B). See the text for a more detailed discussion of these interpretations.

should produce a profound isotopic variation regardless of the studied material. Fig. 8 shows the ${ }^{13} \mathrm{C}_{\text {org }}$ isotopic results of our study (data are in Supplemental Table 3). While there is significant variability in the values ranging from -20.09 to $-28.28 \%$, there is no large magnitude negative excursion as in other continental Permian sites (Retallack et al., 2006). All of the heaviest values come from coals, ranging from -20.83 to $-21.08 \% \delta^{13} \mathrm{C}_{\text {org }}$, or from samples of fragments of stems $\left(-20.09\right.$ to $\left.-21.95 \% \circ{ }^{13} \mathrm{C}_{\mathrm{org}}\right)$. The lighter values all come from detrital samples, and there is a systematic offset between the two types of data. There are two non-diagenetic explanations for this discrepancy. Fire (i.e., charcoalificaton) may shift the isotopic values of organic matter by $>+3 \%$, however, it seems unlikely that only the recognizable fossil plant material would have been impacted by fire. A second possible mechanism would be from selective microbial decomposition (e.g., Wynn, 2007), which leaves residual carbon enriched (i.e., shifted positive) relative to its initial composition. The third possibility for this discrepancy is diagenesis. Given that the pedogenic carbonates of the Alcotas Formation show consistent petrographic evidence for diagenetic alteration (Benito et al., 2005, 2011), this could also explain the two distinctive pools of ${ }^{13} \mathrm{C}_{\text {ong }}$ data, because whereas the stem and coal values are anomalous relative to other continental end-Guadalupian sites, the detrital values match the range commonly observed at both high- and low-paleolatitude sites elsewhere.

In the Iberian Basin we have not detected a profound negative shift in the carbon isotope data. Instead, the minor shifts in the ${ }^{13} \mathrm{C}_{\text {org }}$ values are more likely to be related to changes in the paleoclimatic conditions, paleovegetation, or water availability. The absence of negative shifts will be discussed in Section 6 .

\subsection{Paleoclimatology}

The climate during the deposition of the Boniches Formation, the Valdemeca Unit, and the Cañizar Formation has been described previously in López-Gómez and Arche (1993b, 1997), López-Gómez et al. (2002), Bourquin et al. (2007, 2011), Linol et al. (2009), and references therein. A generally humid paleoclimate is supported by internal sedimentary structures of the conglomerates, which indicate frequent depositional events, and the lack of arid-paleoclimate indicators such as ventifacts, desert varnish on pebbles, or evaporate deposition, limited preservation of easily weatherable minerals (e.g., K-feldspar and biotite), and abundant kaolinite (Alonso-Azcárate et al., 1997; López-Gómez and Arche, 1997).
Well-developed carbonate paleosols with thick perocalcic horizons are found in the ransition zone between Boniches and Alcotas formations. Petrocalcic horizons are commonly associated with long-lived soils formed under arid to semiarid climates (Gile et al, 1981; Retallack, 2001). However, in the formation of certain types of laminar calcretes, the activity of root systems and other micro-organism is essential (Wright et al., 1988; Jones, 1992; Mack and James, 1994), and therefore humid conditions during some part of the year, suitable for this kind of vegetation, cannot be ruled out in the lower part of LS (De la Horra et al., 2008). This possibility is supported by a large number of multi-storey bodies in the infilling of channels, with noticeable reactivation surfaces and erosive bases (Arche and López-Gómez, 2005). Moreover, in the Rodeno paleosols of this lower part of the LS, the Bk depth is greater than in the upper part of the LS. This shift to more arid conditions through the LS is also supported by palynological data that correspond to a depauperate coniferous forest without shrubland vegetation (Diéguez and Barrón, 2005; De la Horra et al., 2008).

In contrast, in the MS forest vegetation was accompanied by dense shrubland vegetation of lycopsids (Diéguez and Barrón, 2005), suggesting a return to humid climatic conditions. This vegetation shift was accompanied by a sedimentological shift to highly sinuous, meandering-stream deposits. Both Bk depths and paleosol geochemistry also indicate wetter conditions (Figs. 5 and 6), which are further supported by the presence of siderite in paleosols, black and green mudstones, coal flakes, pyrite, a loss of carbonate paleosols in the middle and top of the MS, and the predominance of sandy pedotypes (Fig. 4) (Benito et al., 2005; López-Gómez et al., 2005a; De la Horra et al., 2008).

Although there are relatively few paleoclimatic indicators in the US, humid paleoclimatic conditions are inferred throughout the unit based on the lack of pedogenic carbonates, paleoprecipitation values $>800 \mathrm{~mm} \mathrm{yr}^{-1}$ based on paleosol geochemistry, and the relatively poorly developed paleosols. In the Valdemeca section (Figs. 3 and 5) the paleosols have drab-haloed root traces, greenish mottling, slickensides, and desiccation cracks, suggesting moderate to good drainage conditions and seasonal waterlogging (various; e.g., Kraus and Aslan, 1993; Sheldon, 2005).

\section{Discussion}

Fig. 9 summarizes the Middle to Upper Permian continental stratigraphic record from the Iberian Basin. There are two paleoclimatic 


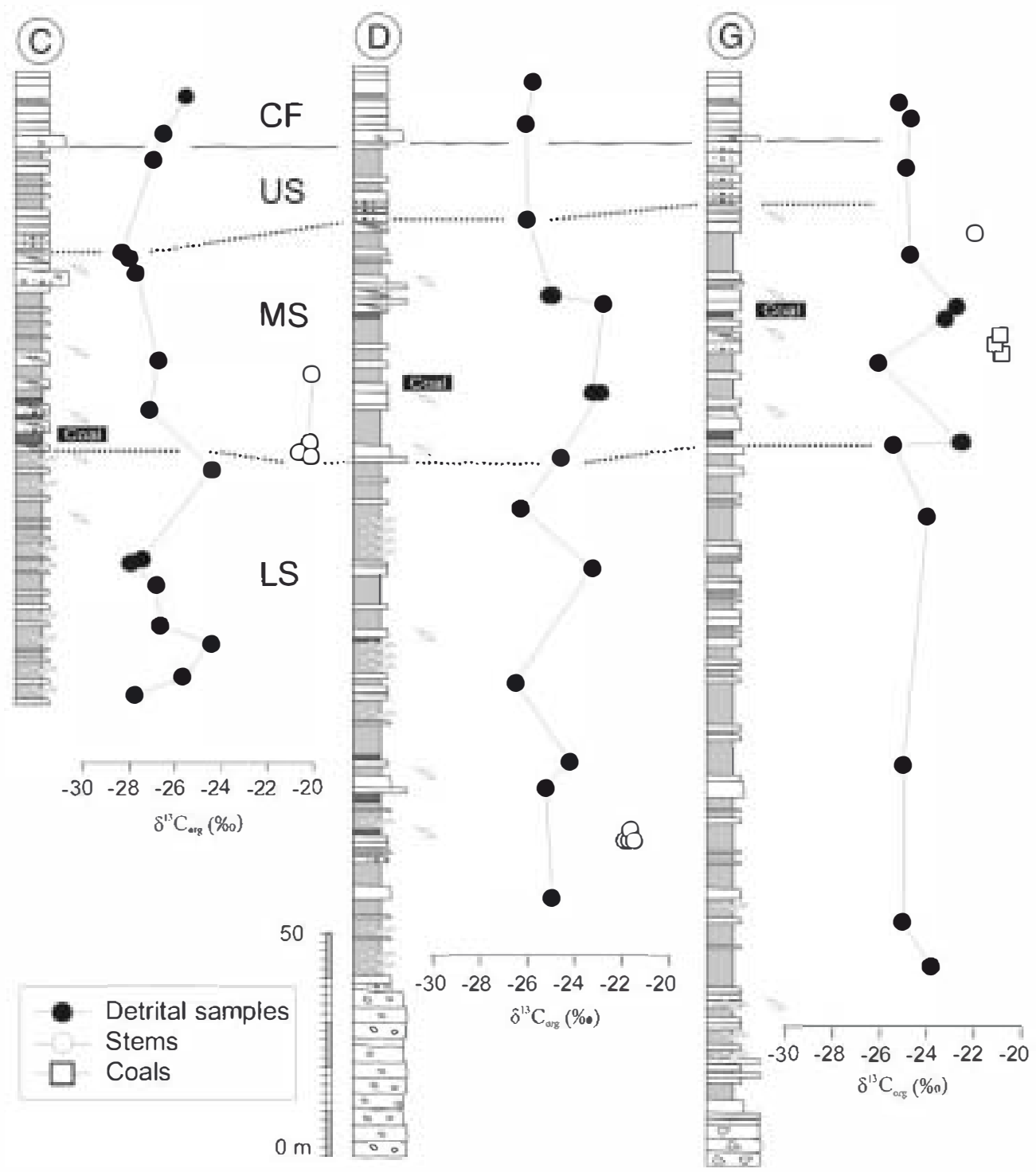

Fig. 8. ${ }^{13} \mathrm{Corg}_{\text {o }}$ isotope curves for the Iandete, Talayuelas, and Montán sections. See Fig. 1 for its location. Lithologic symbols as in Fig. 3.

wet-dry cycles recorded. The first, of short duration, was related to the wet alluvial fans and gravel-bed braided rivers of the Boniches Formation (López-Gómez and Arche, 1997). A period of arid and semiarid palaeoclimatic conditions, where aridisols developed during the sedimentation of the LS, separates this first wet phase from the second wet event, which coincides with the MS. During the second wet phase the oligotrophic and depauperate vegetation of LS shifted to dense conifer forests with abundant shrubland vegetation adapted to high-humidity conditions (Diéguez and Barrón, 2005). In these wetter environments, peat-forming plants accumulated and coals were formed. Although they are rare and thin, the coals are the last observed in Iberia until Middle Triassic times. The palaeoclimatic indicators in the US are consistent with a seasonal climate with alternation of humid and dry conditions. However, it is important to point out that the coal, macro- and microfloral remains, and the paleosols that characterized the IS and the MS of the Alcotas Formation are not preserved at all in the rocks of US in all the Permian SE Iberian Basin. Furthermore, the second humid phase is coincident with a local biotic crisis, detected by an important decrease in the amount and diversity of palynomorphs (Diéguez and Barrón, 2005), macro-flora (Diéguez et al., 2007), and absence of paleosols (De la Horra et al., 2008).
In order to establish correlations with other basins three key questions should be considered: 1 ) what is the precise age of the rocks? 2) Are we dealing with an extinction event in the Iberian Basin or just with a local facies change that affected the palynomorph record? 3) If finally there is an extinction event, is it just local, or could it be related to a global event? With reference to the first key question, the correlation of continental successions without an accurate datation of the rocks could be theoretical rather than demonstrable. One difficulty in particular comes from the need to correlate continental successions with marine given that all of the Permian index fossils are marine, and as a result continental succession has traditionally had poor or inadequate age model precision (Lucas et al., 2006). Examples of this problem range from potentially intractable (Tabor et al., 2011) to unresolved, but potentially resolvable with further work (Yang et al., 2010). As observed in Section 4, without marine correlations, the difficulties of dating continental rocks are enormous and further work should be required to get a better age constraint. However, based on the combination of palinological and paleomagnetic data, in this study we locate the lower part of the Alcotas Formation in the period of time between 265.8 and $260.4 \mathrm{Ma}$, close to the Middle-Late Permian transition. In addition, the use of sedimentary indicators of palaeoclimatic conditions can provide powerful tools 
sedimentological reasons that prevented their preservation. Moreover, the retum of the braided systems in the US is not joined by a drastic change in the climate (Fig. 9) and, in fact, this change of fluvial style is probably related to a rapid dieback of the floodplain vegetation. Episodes of extensive plant die-off has been proposed as the main cause of the vertical transition from high-sinuosity rivers to sandy braided river systems during the Permian-Triassic transition in the Karoo Basin, South Africa (Smith, 1995; Ward et al, 2000), Australia (Michaelson, 2002; Retallack et al., 2011), and Antarctica (Retallack et al., 2005; 2007; Sheldon, 2006). A dieback of vegetation also has direct consequences for the preservation and type of paleosols. The US preserves only a few very weakly developed paleosols in the upper part of the Alcotas Formation in the northwestem sections (Fig. 3).

Finally, if the two previous main points of this discussion are consistent with an extinction event in a period of time close to the Middle-Late Permian transition, we can address the last of the key questions. Is this extinction a local event or could be related to the mid-Capitanian global perturbations described in terrestrial and marine settings by Bond et al. (2010a,b)? This question is, probably, the most difficult to answer because we have to deal with the uncertainties in the datation of the Alcotas Formation. However, beginning with Retallack et al. (2006), there has been a growing consensus about criteria for identifying the mid-Guadalupian extinction in continental settings that include: 1) dramatic biodiversity decline or mass extinction in both flora and fauna, 2) shift from high-sinuosity meandering to braided fluvial systems, 3) evidence for enhanced chemical weathering, 4) evidence for wetter climatic conditions, 5) and a large magnitude negative shift in the composition of ${ }^{13} \mathrm{C}_{\text {org }}$ (typically $>-3 \%$, but sometimes smaller, e.g., Retallack et al., 2011). In the SE Iberian Basin, we have observed all of these criteria in the transition from the MS to the US except for the $\delta^{13} C_{\text {org }}$ shift. However, the data presented in this article show that the characteristics of the extinction interval are observed in all the Iberian Basin, and thus we interpreted this biotic crisis of regional character. If this interpretation is correct, then the only identified crisis in this period of time is the "mid-Capitanian" one. We are aware of the poor age constrain of the Alcotas Formation sediments, but they contain the time interval when the aforementioned crisis happened and provisionally assigning the Iberian extinction event to the mid-Capitanian biotic crisis is the only plausible hypothesis.

The mid-Capitanian extinction scenario has been linked to the Emeishan large igneous province (Wignall, 2001; Ali et al., 2002; Zhou et al., 2002; Lai et al., 2008; Bond and Wignall, 2009; Wignall et al., 2009; Bond et al., 2010b; Wignall et al., 2012). Although the addition of a volcanic aerosol could provide the extra strontium and phosphorous found in the US, we have not observed any evidence of volcanic glass in the thin sections that we have examined and, therefore we do not have direct evidence for the Emeishan volcanic event. However, another possibility is the existence of a volcanic event located closer to the area of study. Recently, a multiple basic to intermediate sill has been reported for the first time in the south-eastern Iberian Ranges. Radiometric dating of the sill is not feasible due to its significant alteration, but field criteria suggest an emplacement coeval to the deposition of the Alcotas Formation, something that is still to be proven (Lago et al., 2011).

Major efforts, including a complete palaeomagnetic study, higher resolution $\delta^{13} \mathrm{C}_{\text {org }}$ analyses, and detailed studies of possible volcanic source, should be required in the Iberian Basin and other continental Permian basins, in order to clarify some of the events that characterized this period of time on land.

\section{Conclusions}

Study of Middle-Late Permian continental rocks of the Alcotas Formation in the SE Iberian Basin reveals a regional paleoclimatic change from arid-semiarid to humid conditions, and a shift to a more intense weathering, as indicated by mineralogical and geochemical data, the absence of carbonate-bearing paleosols, the presence of pyrite- and coal-rich levels, and an increase of lycopsids. During this shift to a humid paleoclimatic phase, a biotic crisis described on the basis of palynological analysis is correlated in the whole basin with the absence of macro- and microflora, coal levels, paleosols, and with a change of fluvial style from meandering to braided systems that is similar to sites in Antarctica and South Africa (Retallack et al., 2006). Based upon palynological and paleosol results, and comparison with other marine and continental records, this climatic shift is associated with the mid-Capitanian mass extinction event. In contrast to other marine and continental records, we find little evidence of a significant negative ${ }^{13} \mathrm{C}_{\text {org }}$ shift associated with the extinction, although given that the magnitude of the shift is regionally variable (e.g., de Wit et al., 2002 vs. Retallack et al., 2006), our record does not preclude a significant carbon cycle reorganization, nor does it allow us to pin down a definitive causal mechanism. However, given the significant climatic shifts observed in Iberia and in a number of other continental records, and the approximate synchroneity of the emplacement of the Emeishan Traps in China, we find this to be the most likely explanation for the observed extinction event.

Supplementary data to this article can be found online at http:// dx.doi.org/10.1016/j.gloplacha.2012.06.008.

\section{Acknowled gments}

Financial support was provided by the Project CGL2008-00093 of the Spanish Ministry and Projects UCM-BSCH-GR58/08: Análisis de Cuencas (910429) and Paleoclimas (910198) Universidad ComplutenseComunidad Autónoma de Madrid.

\section{References}

Ali,J.R., Thompson, G.M., Wang, X.Y., 2002. Emeishan basalts (SW China) and the "end Guadalupian" crisis. Magnetostratigraphic constrains. Journal of the Geological Society of London 159, 21-29.

Alonso-Azcárate, J., Arche, A., Barrenechea, J.F., López-Gómez, J., Luque, F.J., Rodas, M., 1997. Paleogeographical significance of clay mineral assemblages in the Permian and Triassic sediments of the SE Iberian Ranges. Paleogeography, Paleoclimatology, Paleoecology 136 (1-4), 309-330.

Alonso-Zarza, A.M., 2003. Palaeoenvironmental significance of palustrine carbonates and calcretes in the geological record. Earth-Science Reviews 60, 261-298.

Arche, A., López-Gómez, J., 1996. Origin of the Permian-Triassic Iberian Basin, Central Spain. Tectonophysics $266,433-464$.

Arche, A., López-Gómez, J., 1999. Subsidence rates and fluvial architecture of riftrelated Permian and Triassic alluvial sediments of the southeastern Iberian Range, eastern Spain. In: Smith, N.D., Rogers, N. (Eds.), Fluvial Sedimentology: VI: Special Publication of the LAS, 28, pp. 283-304.

Arche, A., López-Gómez, J., 2005. Sudden changes in fluvial style across the PermianTriassic boundary in the eastern Iberian Ranges, Spain: analysis of possible causes. Paleogeography, Paleoclimatology, Paleoecology 229 (1-2), 104-106.

Arche, A., López-Gómez, J., Marzo, M., Vargas, H., 2004. The siliciclastic Permian-Triassic deposits in Central and Northeastern Iberian Peninsula (Iberian, Ebro and Catalan Basins): a proposal for correlation. Geologica Acta 2, 305-320.

Baud, A., Magaritz, M., Holser, W.T., 1989. Permian-Triassic of the Tethys: carbon isotope studies. Geologische Rundschau 78, 649-677.

Benito, M.I., De la Horra, R., Barrenechea, J.F., López-Gómez, J., Rodas, M., AlonsoAzcárate, J., Arche, A., Luque, F.J., 2005. Iate Permian continental sediments in the SE Iberian Ranges, eastern Spain: petrological and mineralogical characteristics and paleoenvironmental significance. Paleogeography, Paleoclimatology, Paleoecology 229 (1-2), 24-39.

Benito, M.I., De la Horra, R., López-Gómez, J., Barrenechea, J.F., Luque, F.J., Arche, A., 2011. Shallow burial dolomitization of Middle-Upper Permian paleosols in an extensional tectonic context (SE Iberian Basin, Spain): controls on temperature of precipitation and source of fluids. Sedimentary Geology 237 (3-4), 135-149.

Bond, D.P.G., Wignall, P.B., 2009. Iatitudinal selectivity of foraminifer extinctions during the Iate Guadalupian crisis. Paleobiology 35, 465-483.

Bond, D.P.G., Wignall, P.B., Wang, W., Védrine, S., Jiang, H.-S., Lai, X-L, Sun, Y.-D., Newton, R.J., Cope, H., Izon, G., 2010a. The mid-Capitanian (Middle Permian) mass extinction and carbon isotope record of South China. Paleogeography, Paleoclimatology, Paleoecology 292, 282-294.

Bond, D.P.G., Hilton, J., Wignall, P.B., Ali, J.R., Stevens, L.G., Sun, Y.D., Lai, X.L., 2010b. The Middle Permian (Capitanian) mass extinction on land and in the oceans. EarthScience Reviews 102, 100-116. 
Bourquin, S., Durand, M., Diez, J.B., Broutin, J., Fluteau, J., 2007. The Permian-Triassic boundary and lower Triassic sedimentation in western European basins: an overview. Journal of Iberian Geology 33 (2), 221-236.

Bourquin, S., Bercovici, A., López-Gómez, J., Diez, J.B., Broutin, J., Ronchi, A., Durand, M., Arche, A., Linol, B., Amour, F., 2011. The Permian-Triassic transition and the onset of Mesozoic sedimentation at the northwestern peri-Tethyan domain scale: paleogeographic maps and geodynamic implications. Paleogeography Paleoclimatology, Paleoecology 299, 265-280.

Clapham, M., Bott jer, D.J., 2006. The rise of the modern evolutionary fauna: decoupled taxonomic and ecological response during the end-Guadalupian extinction. Permophiles 47,10 .

Clapham, M., Shen, S., Bottjer, D., 2009. The double mass extinction revisited: reassessing the severity, selectivity, and causes of the end-Guadalupian biotic crisis (Late Permian). Paleobiology 35 (1), 32-50.

Coney, L., Reimold, W.U., Hancox, J.P., Mader, D., Koeberl, C., McDonald, I., Struck, U., Vajda, V., Kamo, S.L., 2007. Geochemical and mineralogical investigation of the Permian-Triassic boundary in the continental realm of the southern Karoo Basin, South Africa. Paleoworld 16, 67-104.

De la Horra, R., 2008. Variaciones mineralógicas, geoquímicas y bióticas del Pérmico Superior en el Sudeste de la Cordillera Ibérica: Implicaciones paleogeográficas y paleoclimáticas. PhD Thesis, Universidad Complutense, Madrid, 403 pp. Unpublished.

De la Horra, R., López-Gómez, J., Arche, A., 2005. Caracterización de la Unidad Conglomerados de Valdemeca en la transición Pérmico-Triásico de la Cordillera Ibérica centro-orientaL Geotemas 8, 141-145.

De la Horra, R., Benito, M.L, López-Gómez, J., Arche, A., Barrenechea, J.F., Luque, F.J., 2008. Paleoenvironmental significance of Late Permian paleosols in the SE Iberian Ranges, Spain. Sedimentology 55, 1849-1873.

De Vicente, G., Vegas, R., Muñoz-Martín, A., Van Wees, J.D., Casas-Sáinz, Sopeña A., Sánchez-Moya, Y., Arche, A., Iópez-Gómez, J., Olaiz, A., Fernández-Lozano, J., 2009. Oblique strain partitioning and transpression on an inverted rift: the Castilian Branch of the Iberian Chain. Tectonophysics 470, 224-242.

de Wit, M.J., Ghosh, J.G., de Villiers, S., Rakotosolofo, N., Alexander, J., Tripathi, A., Looy, C. 2002. Multiple organic carbon isotope reversals across the Permo-Triassic boundary of terrestrial Gondwanan sequences: clues to extinction patterns and delayed ecosystem recovery. Journal of Geology 110, 227-240.

Diéguez, C., Barrón, E., 2005. Iate Permian flora and vegetation changes near the Perm ian-Triassic boundary in the Landete section of the Alcotas Formation (SE Iberian Ranges, Spain). Paleogeography, Paleoclimatology, Paleoecology 229, 54-68.

Diéguez, C., López-Gómez, J., 2005. Fungus-plant interaction in a Thuringian (Iate Permian) Dadoxylon sp. in the SE Iberian Ranges, eastern Spain. Paleogeography, Paleoclimatology, Paleoecology 229, 69-82.

Diéguez, C., De la Horra, R., Iópez-Gómez, J., Benito, M.L, Barrenechea, J., Arche, A. Luque, J., 2007. Iate Permian plant remains in the SE Iberian Ranges, Spain: biodiversity and paleovegetational significance. Comptes Rendus Palevol 6, 403-411.

Diez, J.B., Broutin, J., Ferrer, J., 2005. Difficulties enountered in defining the Permian-Triassic boundary in Buntsanstein facies of the western Perithetyan domain based on palynological data. Paleogeography, Paleoclimatology, Paleoecology 229, 40-53.

Diez, J.B., Bourquin, S., Broutin, J., Ferrer, J., 2007. The Iberian Permian-Triassic "Buntsandstein" of the Aragonian Branch of the Iberian range (Spain) in the West-European sequence stratigraphical framework: a combined palynological and sedimentological approach. Bulletin de la Société Géologique de France 178 (3), 187-203.

Diez, J.B., Broutin, J., Grauvogel-Stamm, L., Bourquin, S., Bercovici, A., Ferrer, J., 2010 Anisian floras from the NE Iberian Peninsula and Balearic Islands: a synthesis. Review of Paleobotany and Palynology 162, 522-542.

Dinarés-Turell, J., Diez, J.B., Rey, D., Arnal, L, 2005. Buntsandstein magnetostratigraphy and biostratigraphic reappraisal from eastern Iberia: Early and Middle Triassic stage boundary definitions through correlation to Tethyan sections. Paleogeography, Paleoclimatology, Paleoecology 229, 158-177.

Dongying, S., Wenchen, X., 2006. Identification of the Guadalupian-Lopingian boundary in the Permian in a bedded chert sequence, South China. Paleogeography, Paleoclimatology, Paleoecology 236, 272-289.

Doubinger,J., Iópez-Gómez, J., Arche, A., 1990. Pollen and spores from the Permian and Triassic sediments of the Southeastern Iberian ranges, Cueva de Hierro (Cuenca) to Chelva-Manzanera (Valencia-Teruel) region, Spain. Review of Paleobotany and Palynology 66, 25-45

Driese, S.G., Nordt, L.C., Lynn, W., Stiles, C.A., Mora, C.I., Wilding, L.P., 2005. Distinguishing climate in the soil record using chemical trends in Vertiso climosequence from the Texas Coast Prairie, an application to interpreting Paleozoic paleosols in the Appalachian Basin, U.S.A. Journal of Sedimentary Research $75,340-353$.

Erwin, D.H., 1993. The great paleozoic crisis-life and death in the Permian. Columbia University Press, New York, 327 pp.

Galán-Abellán, A.B., Barrenechea, J.F., Iópez-Gómez, J., Iago, M., Luque, F.J., De la Horra, R., Arche, A., Benito, M.L, 2009. Mineralogical and geochemical variations in the continental siliciclastic (Buntsandstein) Early-Middle Triassic units of the Iberian Ranges (Spain). In: Pascucci, V., Andreucci, S. (Eds.), Abstract Book 27th lAS Meeting of Sedimentology. Editrice Democratica Sarda, Sassari, Italy, p. 515

Gand, G., Durand, M., 2006. Tetrapod footprint ichno-associations from French Permian basins. Comparisons with other Euramerican ichnofaunas. In: Lucas, S.G., Cassinis, G., Schneider,J.W. (Eds.), Non-Marine Permian Biostratigraphy and Biochronology, 265. Geological Society Special Publications, London, pp. 157-177.

Gile, L.H., Hawley,J.W., Grossman,J.B., 1981. Soils and geomorphology in the basin and range area of southern New Mexicn-Guidebonk to the desert project. New Mexico Bureau of Mines and Mineral Resources, Memoir 39. Socorro, New Mexico, 222 pp.
Gorsky, V., Gusseva, E., Crasquin-Soleau, S., Broutin, J., 2003. Stratigraphic data of the Middle-Iate Permian on Russian platform. Geobios 36, 533-558.

Goudie, A.S., 1973. Duricrusts in Tropical and Subtropical Landscapes. Claredon, Oxford 174 pp.

Grauvogel-Stamm, L., Ash, S.R., 2005. Recovery of the Triassic land flora from the end Permian life crisis. Comptes Rendus Palevol4, 593-608.

Hallam, A., Wignall, P.B., 1999. Mass extinctions and sea-level changes. Earth-Science Reviews 48, 217-250.

He, B., Xu, Y.G., Huang, X.L., Lou, Z.Y., Shi, Y.R., Yang, Q.J., Yu, S.Y., 2007. Age and duration of the Emeishan flood volcanism, SW China: Geochemistry and SHRIMP zircon $\mathrm{U}-\mathrm{Pb}$ dating of silicic ignimbrites, post-volcanic Xuanwei Formation and clay tuff at the Chaotian section. Earth and Planetary Science Ietters 255, 306-323.

Hemando, S., Schott,J.J., Thuizart, R., Montigny, R., 1980. Ages andésites et des sédiments interstratifiés de la region d'Atienza (Espagne): étude stratigraphique, geochronologique et paleomagnetique. Bulletin de la Société Géologique de France 32, 119-128.

Isozaki, Y., 2009. Integrated "plume winter" scenario for the double-phased extinction during the Paleozoic-Mesozoic transition: the G-LB and P-TB events from a Panthalassan perspective. Journal of Asian Earth Sciences 36, 459-480.

Isozaki, Y., Kawahata, H., Minoshima, K., 2007. The Capitanian (Permian) Kamura cooling event: the beginning of the Paleozoic-Mesozoic transition. Paleoworld $16,16-30$.

Jin, Y.G., Zhang, J., Shang, Q.H., 1994. Two phases of end-Permian mass extinction. Canadian Society of Petroleum Geologists Bulletin 17, 813-822.

Jones, B., 1992. Construction of spar calcite crystals around spores. Journal of Sedimentary Petrology 62, 1054-1057.

Kaiho, K., Chen, Z.Q., Ohashi, T., Arinobu, T., Sawada, K., Cramer, S., 2005. A negative carbon isotope anomaly associated with the earliest Lopingian (Late Permian) mass extinction. Paleogeography, Paleoclimatology, Paleoecology 223, 172-180.

Kisch, H.J., Árkai, P., Brime, C., 2004. On the calibration of the illite Kübler index (illite "crystallinity"). Schweizerische Mineralogische und Petrographische Mitteilungen 84,323-331.

Knoll, A.H., Bambach, R.K., Canfield, D.E., Grotzinger, J.P., 1996. Comparative earth history and Iate Permian mass extinction. Science $272,452-457$

Kraus, M.J., Aslan, A., 1993. Eocene hydromorphic paleosols: significance for interpreting ancient floodplain processes. Journal of Sedimentary Petrology 63, 453-463.

Lago, M., Gil, A., Arranz, E., Galé, C., Pocoví, A., 2005. Magmatism in the intracratonic Central Iberian basins during the Permian: paleoenvironmental consequences. Paleogeography, Paleoclimatology, Paleoecology 229, 83-103.

Lago, M., Galán-Abellán, A.B., Ubide, T., De la Horra, R., Galé, C., Barrenechea,J.F., IópezGómez, J., Benito, M.L, Arche, A., Alonso-Azcárate, J., Luque, F.J., 2011. First Middle Permian alkaline magmatism in the SE Iberian Range? In: Bádenas, B., Aurell, M., Alonso-Zarza, A.M. (Eds.), Abstracts, 28th IAS Meeting of Sedimentology, Zaragoza, Spain, p.492.

Lai, X., Wang, W., Wignal, P., Bond, D.P., Jiang, H., Ali, J.R., John, E.H., Sun, Y., 2008. Paleoenvironmental change during the end-Guadalupian (Permian) mass extinction in Sichuan, China. Paleogeography, Paleoclimatology, Paleoecology 269, 78-93.

Leven, E.J., 2003. Diversity dynamics of fusulinid genera and main stages of their evolution. Stratigraphy and Geological Correlation 11, 220-230.

Linol, B., Bercovici, A., Bourquin, S., Diez, J.B., López-Gómez, J., Broutin, J., Durand, M., Villanueva-Amadoz, U., 2009. Iate permian to middle triassic correlations and palaeogeographical reconstructions in south-western European basins: new sedimentological data from Minorca (Balearic Islands, Spain). Sedimentary Geology $220,77-94$

Looy, C.V., Brugman, W.A., Dilcher, D.L., Visscher, H., 1999. The delayed resurgence of equatorial forests after the Permian-Triassic ecologic crisis. Proceeding of the National Academy of Sciences 96, 13857-13862.

López-Gómez, J., Arche, A., 1986. Evolución sedimentológica de la unidad "Limos y Areniscas de Alcotas". Tramo medio de la facies Buntsandstein en el sector SE de la rama Castellana de la Cordillera Ibérica (Provincias de Cuenca y Valencia). Acta Geológica Hispánica 21-22, 9-18.

López-Gómez, J., Arche, A., 1992. Las unidades litoestratigráficas del Pérmico y Triásico Inferior y Medio en el sector SE de la Cordillera Ibérica. Estudios Geológioos 48, 123-143.

López-Gómez. J. Arche, A. 1993a. Sequence stratigraphy analysis and paleogengraphic interpretation of the Buntsandstein and Muschelkalk facies (Permo-Triassic) in the SE Iberian Ranges, eastern Spain. Paleogeography, Paleoclimatology, Paleoecology $103,347-361$

López-Gómez, J., Arche, A., 1993b. Architecture of the Cañizar fluvial sheet sandstones, Early Triassic, Iberian Ranges, Eastern Spain. Special Publications of the International Association of Sedimentologists 17, 363-381.

López-Gómez, J., Arche, A., 1994. La Formación Brechas de Tabarreña (Pérmico Inferior): Depósitos de flujos con densidad variable al SE de la Cordillera Ibérica, España. Boletín Real Sociedad Española de Historia Natural 89, 131-144.

López-Gómez, J., Arche, A., 1997. The Upper Permian Boniches Conglomerates Formation: evolution from alluvialf an to fluvial system environments and accompanying tectonic and climatic controls in the southeast Iberian Ranges, central Spain. Sedimentary Geology 114, 267-294.

López-Gómez, J., Arche, A., Pérez-López, A., 2002. Permian and Triassic. In: Gibbons, W., Moreno, T. (Eds.), The Geology of Spain. Geological Society, London, pp. 185-212.

López-Gómez, J. De la Horra, R. Benito, M.L, Barrenechea, J.F. Arche, A., Luque, F.J. Alonso Azcárate, J., Diéguez, C., Rodas, M., 2005a. Characteristics of Upper Permian continental sediments and their relationship with the End-Permian crisis in the Southern Iberian Ranges, Spain. New Mexico Museum of Natural History and Science Bulletin 30,172-178.

López-Gómez, J., Arche, A., Marzo, M., Duran, M., 2005b. Stratigraphical and paleogeographical significance of the continental sedimentary transition across the PermianTriassic boundary in Iberia. Paleogeography, Paleoclimatology, Paleoecology 229, 3-23. 
Lucas, S.G., 2009. Timing and magnitude of tetrapod extinctions across the Permo-Triassic boundary. Journal of Asian Earth Sciences 36, 491-502.

Lucas, S.G., Schneider,J.W., Cassinis, G., 2006. In: Lucas, S.G., Cassinis, G., Schneider,J.W. (Eds.), Non-marine Permian biostratigraphy and biochronology: an introduction. Non-Marine Permian Biostratigraphy and Biochronology, 265. Geological Society Special Publications, London, pp. 157-177

Mack, G.H., James, W.C., 1994. Paleoclimate and the Global Distribution of Paleosols Journal of Geology 102, 360-366.

Menning, M., Alekseev, A.S., Chuvashov, B.L, Davydov, V.L, Devuyst, F.-X., Forke, H.C. Grunt, T.A. Hance, L., Heckel, P.H., Izokh, N.G. Jin, Y.-G. Jones, P.J., Kotlyar, G.V. Kozur, H.W. Nemyrovska, T.I., Schneider, J.W. Wang, X.-D. Weddige, K., Weyer D. Work, D.M. 2006. Global time scale and regional stratigraphic reference scales of Central and West Europe, East Europe, Tethys, South China, and North America as used in the Devonian-Carboniferous-Permian Correlation Chart 2003 (DCP 2003). Paleogeography, Paleoclimatology, Paleoecology 240, 318-372.

Michaelson, P., 2002. Mass-extinction of peat-forming plants and the effect on fluvial styles across the Permian-Triassic boundary, northern Bowen Basin, Australia. Palaeogeography, Palaeoclimatology, Palaeoecology 179, 173-188.

Nielsen, J.K.,Shen, Y., 2004. Evidence for sulfidic deep water during the Late Permian in the East Greenland Basin. Geology 32, 1037-1040.

Ogg, J.G., Ogg, G., Gradstein, F.M., 2008. Concise Geologic Time Scale. Cambridge University Press. $177 \mathrm{pp}$.

Pérez-Arlucea, M., Sopeña, A., 1985. Estratigrafia del Pérmico y Triásico en el Sector Central de la Rama Castellana de la Cordillera Ibérica (Provincias de Guadalajara y Teruel). Estudios Geológicos 41, 207-222.

Ponomarenko, A.G., 2006. Changes in terrestrial biota before the Permian-Triassic ecological crisis. Paleontological Journal 40, 468-474

Poort, R.J., Clement-Westerhof, J.A., Looy, C.V., Visscher, H., 1997. Aspects of Permian paleobotany and palynology. 17. Conifer extinction in Europe at the Permian-Trias sic junction: morphology, ultrastructure and geographic/stratigraphic distribution of Nuskoisporites dulhuntyi (prepollen of Ortiseia, Walchiaceae). Reviews of Paleobotany and Palynology 97, 9-39.

Racki, G., Wignall, P.B., 2005. Late Permian double-phased mass extinction and volcanism: an oceanographic perspective. In: Over, D.J., Morrow, J.R., Wignall, P.B. (Eds.), Understanding Iate Devonian and Permian-Triassic Biotic and Climatic Events: Towards an Integrated Approach: Developments in Paleontology \& Stratigraphy, 20 , pp. 263-297.

Ramos, A., 1979. Estratigrafiay paleogeografia del Pérmico y Triásico al oeste de Molina de Aragón (Provincia de Guadalajara). Seminarios de Estratigrafia: Serie Mon ografias, 6. 313 pp.

Retallack, G.J., 2001. Soils of the Past. Blackwell, Oxford. 404 pp.

Retallack, G.J., 2005. Pedogenic carbonate proxies for amount and seasonality of precipitation in paleosols. Geology 33, 333-336.

Retallack, G.J., Smith, R.M.H., Ward, P.D., 2003. Vertebrate extinction across PermianTriassic boundary in Karoo Basin, South Africa. Geological Society of America Bul letin 115, 1133-1152.

Retallack, G.J. Jahren, A.H., Sheldon, N.D., Chakrabarti, R., Metzger, C.A., Smith, R.M.H., 2005. The Permian-Triassic boundary in Antarctica. Antarctic Science 17, 241-258.

Retallack, G.J. Metzger, C.A., Greaver, T.,Jahren, A.H., Sheldon, A.D., Smith, R.M.H., 2006 Middle-Iate Permian mass extinction on land. Geological Society of America Bulletin $118,1398-1411$.

Retallack, G.J., Greaver, T.,Jahren, A.H., 2007. Return to Coalsack Bluff and the PermianTriassic boundary in Antarctica. Global and Planetary Change 55, 90-108.

Retallack, G.J. Sheldon, N.D., Carr, P.F., Fanning, M., Thompson, C.A., Williams, M.L., Jones, B.G. Hutton, A., 2011. Multiple Early Triassic greenhouse crises impeded re covery from Late Permian mass extinction. Paleogeography, Paleoclimatology, Paleoecology 308, 233-251.

Royer, D.L., 1999. Depth to pedogenic carbonate horizon as a paleoprecipitation indicator? Geology 27, 1123-1126.

Salas, R., Casas, A., 1993. Mesozoic extensional tectonics, stratigraphy and crustal evolution during the Alpine cycle of the eastern Iberian Basin. Tectonophysics 228 33-56.

Schneider, J., Körner, F, Roscher, M., Kroner, U., 2006. Permian climate development in the northern peri-Tethys area: the Iòdeve basin, French Massif Central, compared in a European and global context. Paleogeography, Paleoclimatology, Paleoecology 240, 161-183.

Sheldon, N.D. 2005. Do red beds indicate paleoclimatic conditions? A Permian case study. Paleogeography, Paleoclimatology, Paleoecology 228 (3-4),305-319.

Sheldon, N.D. 2006. Abrupt chemical weathering increase across the Permian-Triassic boundary. Paleogeography, Paleoclimatology, Paleoecology 231, 315-321.

Sheldon, N.D. Retallack, G.J., 2001. A universal equation for compaction due to burial Geology 29, 247-250.

Sheldon, N.D., Tabor, N.J., 2009. Quantitative paleoenvironmental and paleoclimatic reconstruction using paleosols. Earth-Science Reviews 95, 1-52.

Sheldon, N.D., Retallack, G.J., Tanaka, S., 2002. Geochemical climof unctions from North American soils and application to paleosols across the Eocene-Oligocene boundary in Oregon. Journal of Geology 110, 687-696

Shen, J.W., Shu, H.L., 2005. Microbial carbonates as contributors to Upper Permian (Guadalupian-Lopingian) biostromes and reefs in carbonate platform margin setting, Ziyun County, South China. Paleogeography, Paleoclimatology, Paleoecology 218,217-238.

Slowakiewicz, M., Kiersnowski, H., Wagner, R., 2009. Correlation of the Middle and Upper Permian marine and terrestrial sedimentary sequences in Polish, German, and USA Western Interior Basins with reference to global time markers Paleoworld 18, 193-211.
Sobolev, S.V., Sobolev, A.V., Kuzmin, D.V., Krivolutskaya, N.A, Petrunin, A.G, Arndt, N.T., Radko, V.A, Vasiliev, Y.R., 2011. Linking mantle plumes, large igneous provinces and environmental catastrophes. Nature 477, 312-316.

Soil Survey Staff, 1999. Keys to soil taxonomy. Pocahontas Press, Blackburg. 600 pp.

Sopeña, A., López-Gómez, J., Arche, A., Pérez-Arlucea, M., Ramos, A., Virgili, C. Hernando, S., 1988. Permian and Triassic rift basins of the Iberian Peninsula. In: Manspeizer, W., (Ed.), Triassic-Jurassic Rifting. Continental Breackup and the Origin of the Atlantic Ocean and Passive Margins. Part B. Developments in Geotectonics 22. Elsevier, New York, pp. 757-784

Stampfli, G.M., Borel, G.D., 2002. A plate tectonic model for the Paleozoic and Mesozoic constrained by dynamic plate boundaries and restored synthetic oceanic isochrons. Earth and Planetary Science Ietters 196, 17-33.

Stanley, S.M., Yang, X., 1994. A double mass extinction at the end of the Paleozoic era. Science 266, 1340-1344

Stevens, L.G., Hilton, J., Bond, D.P.G., Glasspool, I.J., Jardine, P.E., 2011. Radiation and extinction patterns in Pennsylvanian-Permian floras from North China as indicators for environmental and climate change. Journal of the Geological Society of Iondon $168,607-619$

Tabor, N.J., Montañez, LP., Zierenberg, R., Currie, B.S., 2004. Mineralogical and geochemical evolution of a basalt-hosted fossil soil (Late Triassic, Ischigualasto Formation, northwest Argentina): potential for paleoenvironmental reconstruction Geological Society of America Bulletin 116, 1280-1293.

Tabor, N.J., Smith, R.M.H., Steyer, J.S., Sidor, C.A., Poulsen, C.J, 2011. The Permian Moradi Formation of northern Niger: paleosol morphology, petrography and mineralogy. Paleogeography, Paleoclimatology, Paleoecology 299, 200-213.

Turner, P., Turner, A., Ramos, A., Sopeña, A., 1989. Palaeomagnetism of Permo-Triassic rocks in the Iberian Cordillera, Spain: acquisition of secondary and characteristic remanence. Journal of the Geological Society, London 146, 61-76.

Van Wees, J.D., Arche, A., Beijdorff, C.G., Iópez-Gómez, J., Cloetingh, S., 1998. Temporal and spatial variations in tectonic subsidence in the Iberian Basin (E Spain) Tectonophysics 300, 285-310.

Vargas, H., Gaspar-Escribano, J., López-Gómez, J., van Wees, J.-D., Cloetingh, S., De la Horra, R., Arche, A., 2009. A comparison of the Iberian and Ebro Basins during the Permian and Triassic, eastern Spain: a quantitative subsidence modelling approach. Tectonophysics $474,160-183$

Wang, J., 2009. Late Paleozoic macrofloral assemblages from Weibei Coalfield, with reference to vegetational change through the Iate Paleozoic ice-age in the North China Block. International Journal of Coal Geology 83, 292-317.

Wang, X.D., Sugiyama, T., 2000. Diversity and extinction patterns of Permian coral faunas of China. Iethaia 33, 285-294

Wang, W. Cao, Ch., Wang, Y., 2004. The carbon isotope excursion on GSSP candidate section of Iopingian-Guadalupian boundary. Earth and Planetary Science Letters 220, 57-67.

Ward, P.D. Montgomery, D.R., Smith, R.M.H., 2000. Altered river morphology in South Africa related to the Permian-Triassic extinction. Science 289, 1740-1743.

Wignall, P. 2001. Iarge igneous provinces and mass extinctions. Earth-Science Reviews $53,1-33$

Wignall, P., 2005. The link between large igneous province eruptions and mass extinctions. Elements 1, 293-297.

Wignall, P.B., Twitchett, R.J, 1996. Oceanic anoxia and the end Permian mass extinc tion. Science 272, 1155-1158.

Wignall, P.B., Sun, Y., Bond, D.P.G., Izon, G., Newton, R.J., Védrine, S., Widdowson, M., Ali, J.R. lai, X., Jiang, H., Cope, H., Bottrell, S., 2009. Volcanism, mass extinction, and carbon isotope fluctuations in the Middle Permian of China. Science 234, 1179-1182.

Wignall, P.B., Bond, D.P.G., Kuwahara, K., Kakuwa, K., Newton, R.J., Poulton, S.W., 2010 An 80 million year oceanic redox history from Permian to Jurassic pelagic sedi ments of the Mino-Tamba terrane, SW Japan, and the origin of four mass extinctions. Global and Planetary Change 71, 109-123.

Wignall, P.B., Bond, D.P.G. Haas, J., Wang, W., Jiang, H.-S., Lai, X.-L., Altiner, D., Védrine, S., Hips, K., Zajzon, N. Newton, R.J., 2012. The Capitanian (Middle Permian) mas extinction in western Tethys: a fossil, facies and $\mathrm{d}^{13} \mathrm{C}$ study from Hungary and Hydra Island (Greece). Palaios 27, 78-89.

Wright, V.P., Platt, N.H., Wimbledon, W., 1988. Biogenic laminar calcretes: evidence of calcified root mat horizons in palaeosols. Sedimentology $35,603-620$.

Wynn, J.G., 2007. Carbon isotope fractionation during decomposition of organic matter in soils and paleosols: implications for paleoecological interpretation of paleosols Palaeogeography, Palaeoclimatology, Palaeoecology 251, 437-448.

Yang, X.N., Liu, J.R., Shi, G.J., 2004. Extinction process and patterns of Middle Permian fusulinaceans in southwest China. Lethaia 37, 139-147.

Yang, W., Feng, Q., Liu, Y., Tabor, N., Miggins, D., Crowley, J.L., Lin, J., Thomas, S., 2010 Depositional environments and cyclo- and chronostratigraphy of uppermost Carboniferous-Lower Triassic fluvial-lacustrine deposits, southern Bogda Mountains, NW China - a terrestrial paleoclimate record of mid-latitude NE Pangea. Global and Planetary Change $73,15-113$

Yin, H.F., Feng, Q.L., Lai, X.L., Baud, A., Tong, J.N., 2007. The protracted Permo-Triassic crisis and multi-episode extinction around the Permian-Triassic boundary. Global and Planetary Change 55, 1-20.

Zhou, M.F., Malpas, J., Song, X.Y., Robinson, P.T., Sun, M., Kennedy, A.K., Lesher, C.M. Keays, R.R., 2002. A temporal link between the Emeishan large igneous province (SW China) and the end-Guadalupian mass extinction. Earth and Planetary Science Letters 196, 113-122.

Ziegler, P.A. Stampfli, G.M., 2001. Late Paleozoic Early Mesozoic plate boundary reorganisation: collapse of the Variscan orogen and opening of Neotethys. In: Cassinis, R. (Ed.), The Continental Permian of the Southern Alps and Sardinia (Italy) Regional Reports and General Correlations: Annali Museo Civico Science Naturali, Brescia, Brescia, pp. 17-34. 